\title{
5. LATE MIOCENE TO HOLOCENE PLANKTONIC FORAMINIFERS FROM THE EQUATORIAL ATLANTIC, LEG 108 $^{1}$
}

\author{
P.P.E. Weaver ${ }^{2}$ and M. E. Raymo ${ }^{3}$
}

\begin{abstract}
Planktonic foraminifers were examined from 27 holes situated at 12 separate sites in the tropical Atlantic. The sites are located in various environments, including areas of upwelling, areas affected by cool currents, areas of strong dissolution, and areas that show little dissolution in warm-water settings. Paleomagnetic results were variable at these sites, but accumulation rate curves have been produced by combining the existing paleomagnetic data with the available microfaunal data. Determinations of the ages of the planktonic foraminifer datums from these accumulation rate curves show some species to be strongly diachronous, while others provide good stratigraphic markers. The warmest water sites with the least dissolution show the most complete ranges of species.
\end{abstract}

\section{INTRODUCTION}

Leg 108 of the Ocean Drilling Program (ODP) drilled 27 holes at 12 sites in the low-latitude Atlantic Ocean to study the paleoceanography and paleoclimatology of the Neogene (Fig. 1, Table 1). Essential to any such study is a sound stratigraphy, which can be achieved in the upper Quaternary by oxygen isotope measurements. This method is less reliable further back in time, however, and recourse must be made to planktonic foraminifers, nannofossils, and-wherever possible-magnetic stratigraphy.

In spite of numerous publications on low-latitude planktonic foraminifer stratigraphy, no accepted zonal scheme can be applied worldwide. In this work we examine the datums used in some of these low-latitude zonations, such as those of Bolli and Premoli Silva (1973) and Blow (1969), as well as some of the datums from the mid-latitude zonations set up by Berggren (1973, 1977a, 1977b) and Weaver and Clement (1986).

All the sites drilled on Leg 108 lie in the eastern tropical Atlantic, but the cool Canary and Benguela Currents and the northwest African and tropical upwelling systems have strongly influenced faunal compositions at most of the sites. Sites 667 and 668 were influenced the least by these factors and are therefore the most truly tropical. In addition, Sites $658,660,661,665$, and 666 exhibit considerable dissolution, which has biased their faunal makeup by reducing or eliminating the more susceptible species.

Sediment redistribution by slumps and turbidites has complicated the stratigraphy of some of the sites, particularly Sites $557,662,663$, and 664 . In most cases, it is possible to determine the upper and lower boundaries of the displaced units, but any associated erosion is difficult to assess.

\section{MATERIALS AND METHODS}

Samples were prepared by drying and then soaking in water. This was sufficient to give a complete breakdown in most cases, although in some harder samples it was necessary to repeat the process. All samples were washed through a $63-\mu \mathrm{m}$ sieve, and the analyses were carried out on the $>150-\mu \mathrm{m}$ fraction.

\footnotetext{
${ }^{1}$ Ruddiman, W., Sarnthein, M., et al., 1989. Proc. ODP, Sci. Results, 108: College Station, TX (Ocean Drilling Program).

Institute of Oceanographic Sciences, Brook Road, Wormley, Godalming, Surrey GU8 5UB, United Kingdom.

${ }^{3}$ Lamont-Doherty Geological Observatory, Palisades, NY 10964.
}

We have used the taxonomy of Kennett and Srinivasan (1983) throughout; reference should be made, therefore, to this work for all taxonomic information.

\section{STRATIGRAPHY}

The last $20 \mathrm{yr}$ have seen the development of numerous Neogene stratigraphies based on planktonic foraminifers (e.g., Blow, 1969; Bolli and Premoli Silva, 1973; Cita, 1973; Kennett, 1973; Stainforth et al., 1975; Berggren, 1973, 1977a, 1977b; Berggren et al., 1983; and Weaver and Clement, 1986, 1987). Few of these works, with the exception of those by Berggren et al. and Weaver and Clement, have had the benefit of direct comparison to paleomagnetic records from the same cores, although Berggren et al. (1985) found paleomagnetic corroboration from various sources for most of the datums outlined in Berggren (1973, 1977a, 1977b).

Using a north-south transect of hydraulic piston cores, all with above average accumulation rates, few hiatuses, and good paleomagnetic control, Weaver and Clement (1986, 1987) critically assessed the applicability of earlier Neogene zonations to the subtropical and temperate North Atlantic. They found that some well-established zonal markers were very diachronous, while others were synchronous in their occurrence with latitude. Weaver and Clement also used several new species as zonal markers, thus maintaining the high degree of stratigraphic resolution possible in the late Neogene.

Hodell and Kennett (1986) also found diachronous foraminifer datums between widely spaced deep sea sites in the South Atlantic and Southwest Pacific. Thus, foraminifer stratigraphy appears to be much more complicated than previously anticipated, and a zonal scheme determined in one area cannot always be used with ease elsewhere. Indeed, the data from this leg does not fit any one zonal scheme; but, by estimating first (FO) and last (LO) occurrences for many species in all the sites, we have tried to determine the reliability of stratigraphic markers in the eastern tropical Atlantic.

The ages estimated for the datums in each site are derived from the accumulation rate curves (Fig. 2). These were produced using paleomagnetic and nannofossil data in addition to the foraminifer datums listed in Berggren et al. (1985). (Reference should be made to the relevant chapters in the Proceedings of the Ocean Drilling Program: Initial Reports to identify the exact procedure for each site.) Some of the zonal schemes mentioned in the text are shown in Figure 3, with comparisons to the paleomagnetic record where possible. 


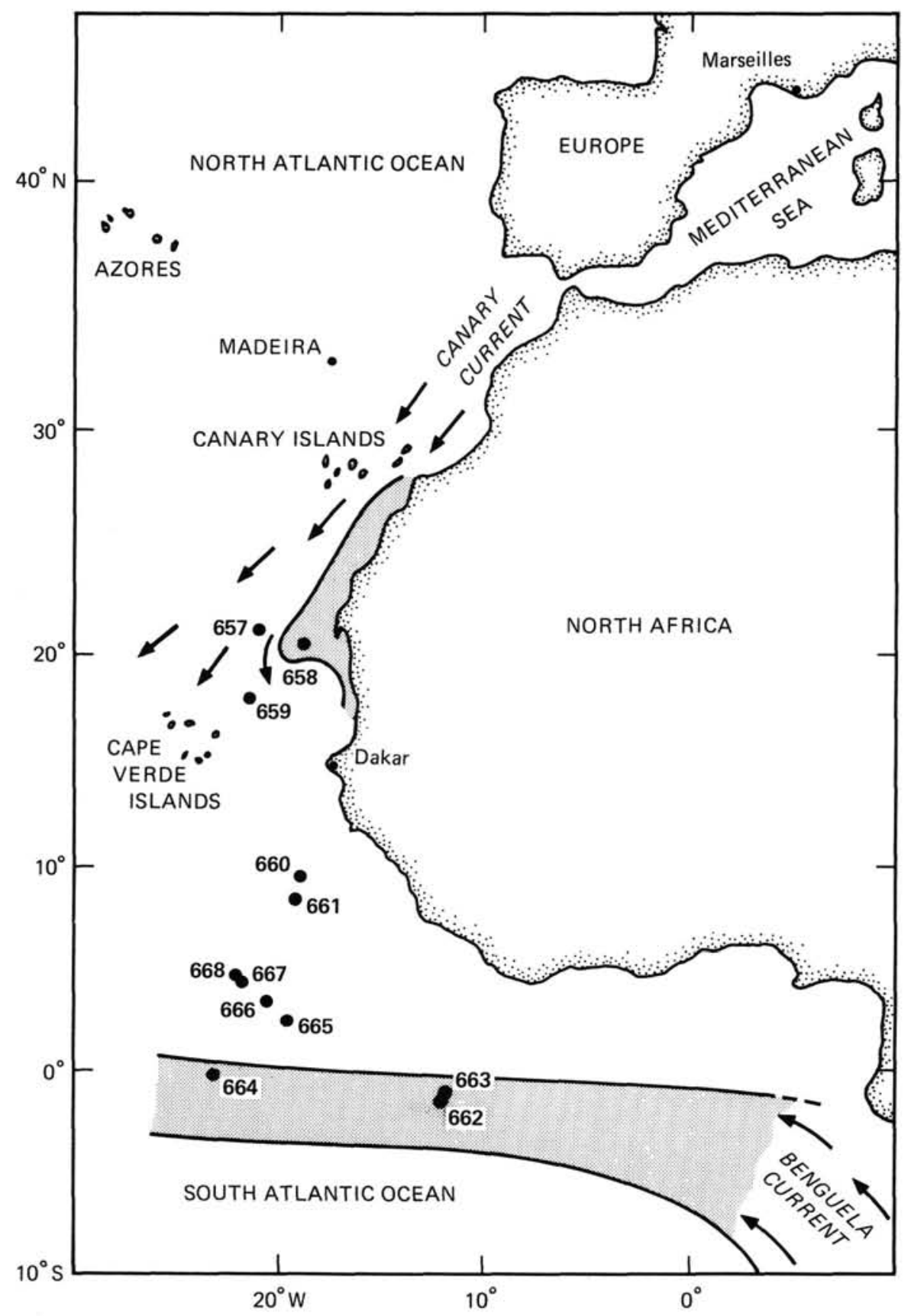

Figure 1. Geographic position of Leg 108 sites. Arrows mark major current systems; dotted areas indicate regions of strong Pliocene-Pleistocene upwelling and divergence.

The sites drilled on Leg 108 are generally too far south to use planktonic foraminifer datums from the Pliocene temperate zonation of Weaver and Clement (1986), although some of their zonal boundaries are recognizable. For the Miocene, we have used the zonation of Berggren et al. (1983) where possible. The low-latitude zonation of Bolli and Premoli Silva (1973), recently described in detail by Bolli and Saunders (1985), was not applicable at these sites. Its usefulness may be limited to the Caribbean region, where it was originally defined.
None of the Leg 108 sites has complete paleomagnetic control, and some have no control at all; thus, the accumulation rate diagrams are based largely on microfossil data. The accuracy of the accumulation rate curves depends on the correct age assignments for the datums used in their construction. Since some of these are potentially diachronous, errors may occur. In most cases we have been able to use large numbers of datums, through which we were able to draw best-fit lines that account for most of the data. We are confident of the accuracy of the accumulation rate curves for 
Table 1. Location, water depth, and depth penetrated of holes drilled on Leg 108.

\begin{tabular}{|c|c|c|c|c|c|}
\hline Site & Hole & Latitude & Longitude & $\begin{array}{c}\text { Water } \\
\text { depth } \\
\text { (m) }\end{array}$ & $\begin{array}{l}\text { Depth } \\
\text { (mbsf) }\end{array}$ \\
\hline 657 & A & $21^{\circ} 19.89^{\prime} \mathrm{N}$ & $20^{\circ} 56.93^{\prime} \mathrm{W}$ & 4221.1 & 178.2 \\
\hline 657 & B & $21^{\circ} 19.89^{\prime} \mathrm{N}$ & $20^{\circ} 56.93^{\prime} \mathrm{W}$ & 4221.1 & 166.1 \\
\hline 658 & A & $20^{\circ} 44.95^{\prime} \mathrm{N}$ & $18^{\circ} 34.85^{\prime} \mathrm{W}$ & 2263.6 & 300.4 \\
\hline 658 & B & $20^{\circ} 44.95^{\prime} \mathrm{N}$ & $18^{\circ} 34.85^{\prime} \mathrm{W}$ & 2264.2 & 163.8 \\
\hline 658 & $\mathrm{C}$ & $20^{\circ} 44.95^{\prime} \mathrm{N}$ & $18^{\circ} 34.85^{\prime} \mathrm{W}$ & 2262.9 & 72.9 \\
\hline 659 & A & $18^{\circ} 04.63^{\prime} \mathrm{N}$ & $21^{\circ} 01.57^{\prime} \mathrm{W}$ & 3071.2 & 273.8 \\
\hline 659 & B & $18^{\circ} 04.63^{\prime} \mathrm{N}$ & $21^{\circ} 01.57^{\prime} \mathrm{W}$ & 3073.4 & 202.0 \\
\hline 659 & C & $18^{\circ} 04.63^{\prime} \mathrm{N}$ & $21^{\circ} 01.57^{\prime} \mathrm{W}$ & 3070.5 & 196.0 \\
\hline 660 & A & $10^{\circ} 00.81^{\prime} \mathrm{N}$ & $19^{\circ} 14.74^{\prime} \mathrm{W}$ & 4332.2 & 163.7 \\
\hline 660 & B & $10^{\circ} 00.81^{\prime} \mathrm{N}$ & $19^{\circ} 14.74^{\prime} \mathrm{W}$ & 4332.3 & 148.8 \\
\hline 661 & A & $09^{\circ} 26.81^{\prime} \mathrm{N}$ & $19^{\circ} 23.17^{\prime} \mathrm{W}$ & 4012.7 & 296.1 \\
\hline 661 & B & $09^{\circ} 26.81^{\prime} \mathrm{N}$ & $19^{\circ} 23.17^{\prime} \mathrm{W}$ & 4013.1 & 81.7 \\
\hline 662 & A & $01^{\circ} 23.41^{\prime} \mathrm{S}$ & $11^{\circ} 44.35^{\prime} \mathrm{W}$ & 3813.8 & 200.0 \\
\hline 662 & B & $01^{\circ} 23.41^{\prime} \mathrm{S}$ & $11^{\circ} 44.35^{\prime} \mathrm{W}$ & 3813.8 & 188.2 \\
\hline 663 & A & $01^{\circ} 11.87^{\prime} \mathrm{S}$ & $11^{\circ} 52.71^{\prime} \mathrm{W}$ & 3697.6 & 147.2 \\
\hline 663 & B & $01^{\circ} 11.87^{\prime} \mathrm{S}$ & $11^{\circ} 52.71^{\prime} \mathrm{W}$ & 3697.4 & 152.0 \\
\hline 664 & A & $0^{\circ} 06.44^{\prime} \mathrm{N}$ & $23^{\circ} 13.65^{\prime} \mathrm{W}$ & 3806.0 & 28.9 \\
\hline 664 & B & $0^{\circ} 06.44^{\prime} \mathrm{N}$ & $23^{\circ} 13.65^{\prime} \mathrm{W}$ & 3806.3 & 247.0 \\
\hline 664 & C & $0^{\circ} 06.44^{\prime} \mathrm{N}$ & $23^{\circ} 16.50^{\prime} \mathrm{W}$ & 3806.8 & 61.2 \\
\hline 664 & D & $0^{\circ} 06.44^{\prime} \mathrm{N}$ & $23^{\circ} 16.50^{\prime} \mathrm{W}$ & 3801.7 & 296.8 \\
\hline 665 & A & $2^{\circ} 57.07^{\prime} \mathrm{N}$ & $19^{\circ} 40.07^{\prime} \mathrm{W}$ & 4740.4 & 97.9 \\
\hline 665 & B & $2^{\circ} 57.07^{\prime} \mathrm{N}$ & $19^{\circ} 40.07^{\prime} \mathrm{W}$ & 4741.8 & 82.0 \\
\hline 666 & A & $3^{\circ} 29.84^{\prime} \mathrm{N}$ & $20^{\circ} 10.03^{\prime} \mathrm{W}$ & 4516.8 & 150.5 \\
\hline 667 & A & $4^{\circ} 34.15^{\prime} \mathrm{N}$ & $21^{\circ} 54.68^{\prime} \mathrm{W}$ & 3535.5 & 381.3 \\
\hline 667 & B & $4^{\circ} 34.15^{\prime} \mathrm{N}$ & $21^{\circ} 54.68^{\prime} \mathrm{W}$ & 3535.5 & 139.1 \\
\hline 668 & A & $4^{\circ} 46.12^{\prime} \mathrm{N}$ & $20^{\circ} 55.62^{\prime} \mathrm{W}$ & 2690.0 & 8.8 \\
\hline 668 & B & $4^{\circ} 46.12^{\prime} \mathrm{N}$ & $20^{\circ} 55.62^{\prime} \mathrm{W}$ & 2693.1 & 31.2 \\
\hline
\end{tabular}

all sites except Sites 663 and 666, which contain too many sediment disturbances.

\section{FORAMINIFER DISTRIBUTIONS}

\section{Canary Current and Upwelling Sites 657, 658, and 659}

These three sites were selected to study the late Neogene history of northern trade winds and upwelling off the shore of Africa. Sites 657 and 659 were positioned in nonupwelling areas, at 4222 and 3071 meters below seafloor (mbsf), respectively; Site 658 was positioned in the center of the nearby upwelling cell off Cap Blanc in a water depth of $2263 \mathrm{mbsf}$. Sites 657 and 659 lie directly under the Canary Current, which brings cool surface water from the north (Sarnthein et al., 1982).

Although Site 658 penetrated organic-rich sediment to a depth of $300 \mathrm{~m}$, the oldest sediment recovered was early Pliocene. This was because of the high accumulation rates, which averaged over $100 \mathrm{~m} / \mathrm{m}$.y. The considerable dissolution encountered is probably caused by the decaying organic material. Dissolution is particularly severe in the lower parts of the sequence, decreasing through the upper Pliocene and becoming less significant in the Quaternary. Because upwelling keeps the surface water cool, colder water foraminifers such as Neogloboquadrina pachyderma (d) and Globorotalia inflata are common. The most abundant species, however, is Globigerina bulloides, which is known to be common in upwelling waters (Zobel, 1973). Although this site lies in the tropics, tropical species such as Globorotalia tumida, Pulleniatina obliquiloculata, and Sphaeroidinella dehiscens make only sporadic appearances.

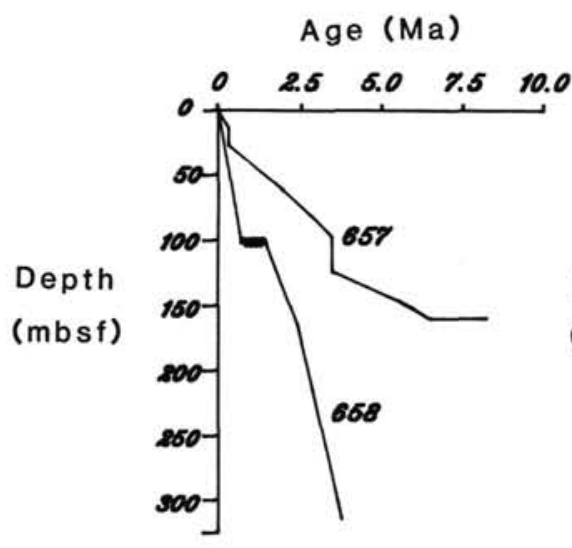

Age (Ma)

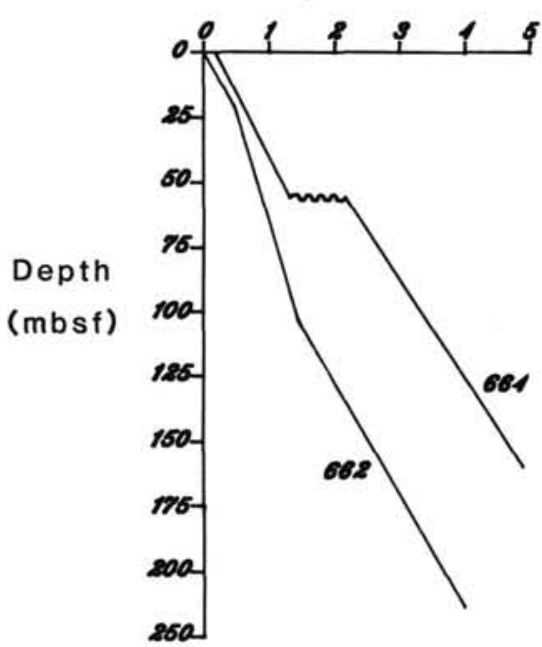

Age (Ma)

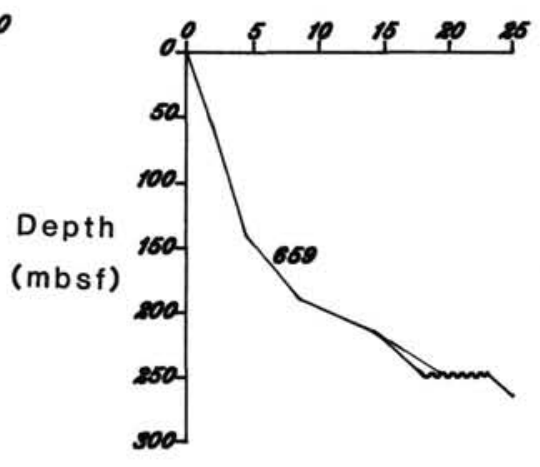

Age (Ma)
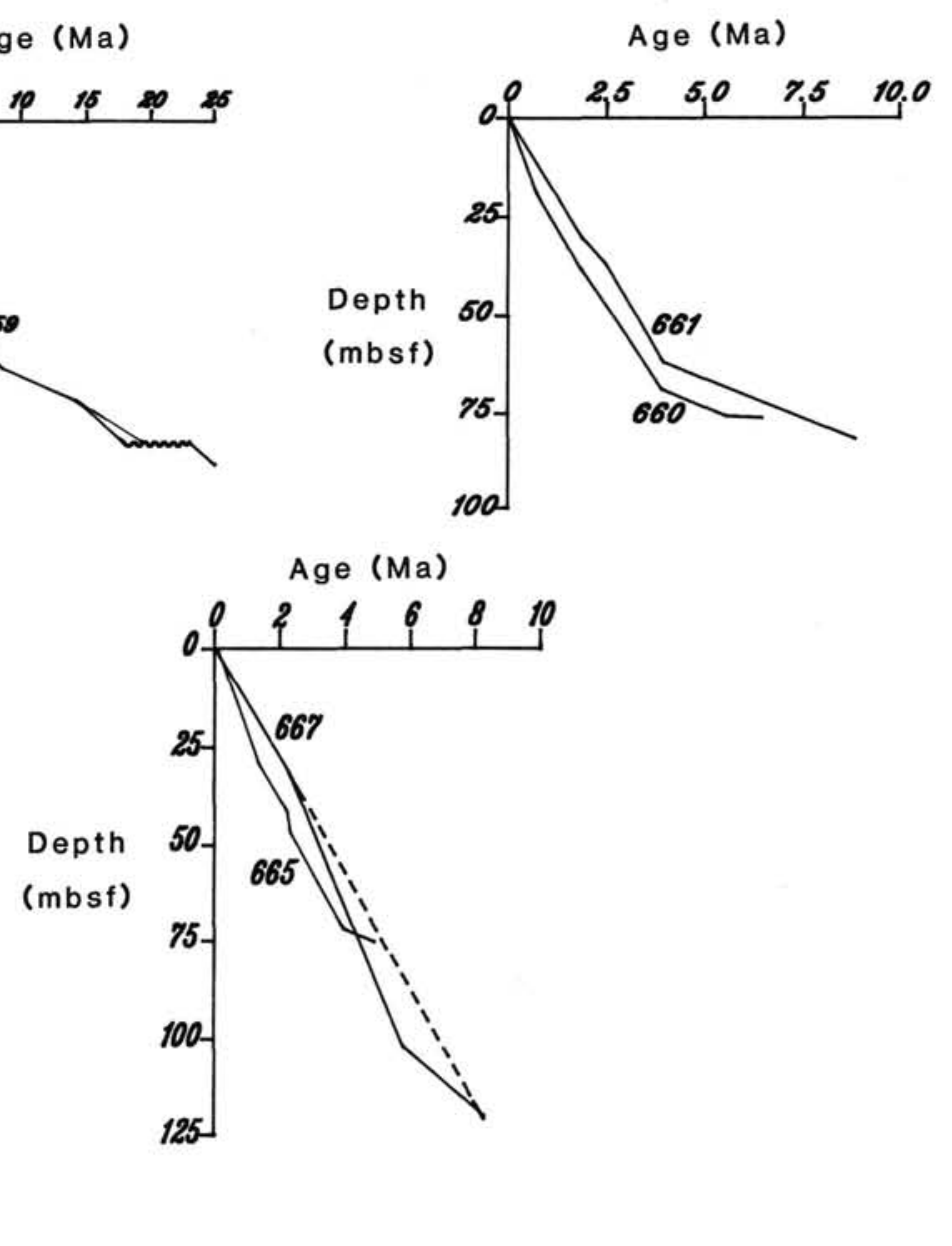

Figure 2. Accumulation rate diagrams for Leg 108 sites from which all datums were calculated. See Weaver et al. (this volume) for explanations of data points used. 


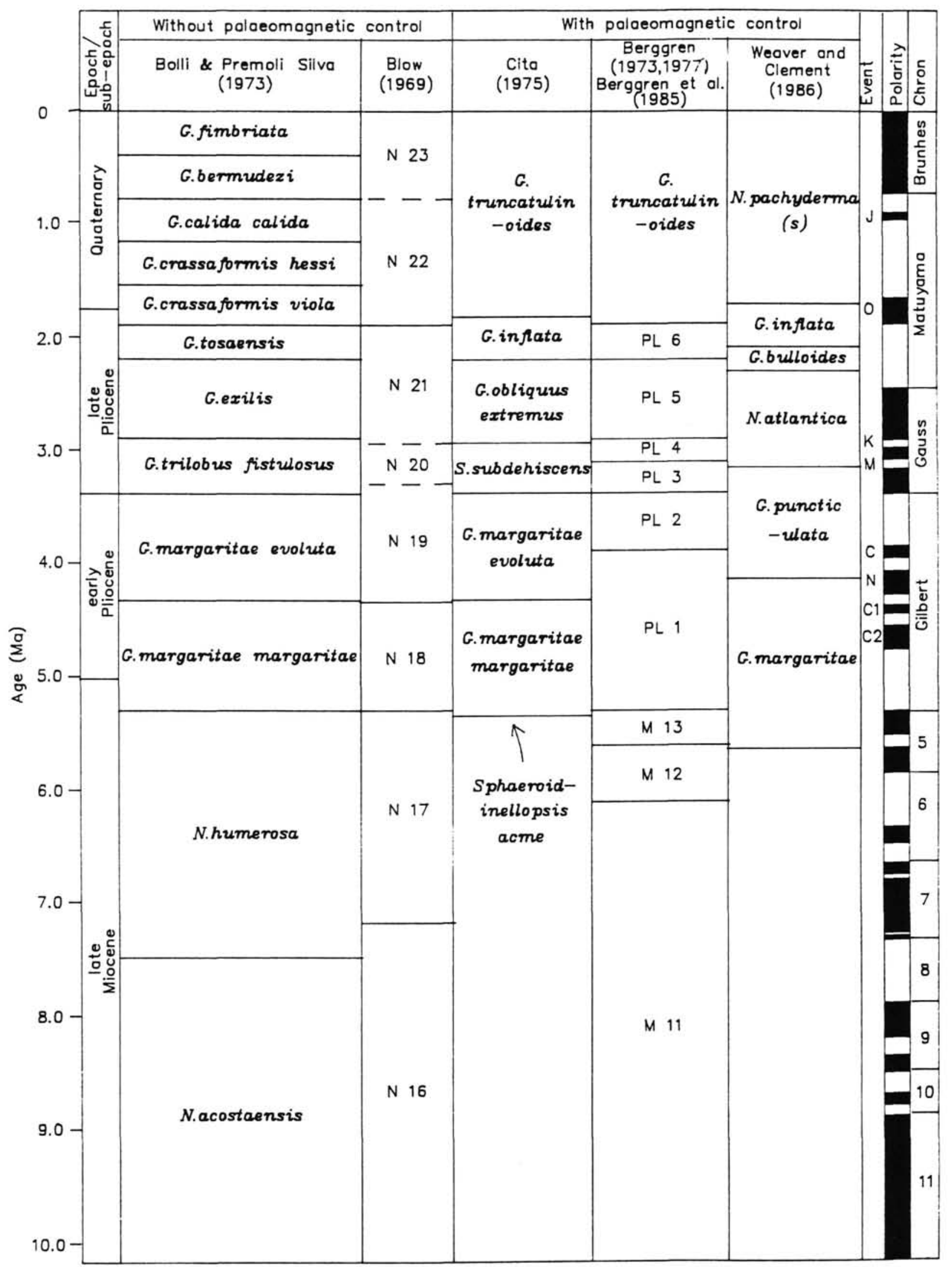

Figure 3. Comparison of some recent planktonic foraminifer zonal schemes for the late Neogene. 
Site 657 penetrated $178 \mathrm{mbsf}$, terminating in the late Miocene, and Site 659 penetrated $274 \mathrm{mbsf}$, terminating in the uppermost Oligocene. Dissolution affected both sites, but it is more severe at Site 657, where late Miocene planktonic foraminifers are extremely rare or absent. They become progressively better preserved through the early Pliocene and are moderately well preserved in the late Pliocene and Quaternary. At Site 659 complete dissolution in the Oligocene is followed by moderate to poor preservation in the Miocene and good preservation in the Pliocene and Quaternary.

The planktonic foraminifer faunas at both sites are composed of cool subtropical and temperate species such as Neogloboquadrina pachyderma, Globorotalia inflata/puncticulata, and Globigerinoides ruber. Globigerina bulloides is still common, but it is not as abundant as at Site 658. The proximity of these sites to warm water is indicated by the occasional occurrence of such tropical species as $S$. dehiscens and $P$. obliquiloculata and the persistent but not common occurrence of Globigerinoides sacculifer.

Through the Quaternary and late Pliocene, the fauna is dominated by $N$. pachyderma (d). Prior to about $2.4 \mathrm{Ma}$, however, this species was less common, possibly indicating a strengthening of the Canary Current coincident with the onset of major Northern Hemisphere glaciation. The abundance of $N$. pachyderma also increased from the end of the Miocene to the end of the PL1 Zone in the early Pliocene, perhaps indicating an earlier period of strong Canary Current flow.

The stratigraphy of these three sites is based on the PL zonal scheme of Berggren (1973, 1977a, 1977b) and the temperate subpolar zonation of Weaver and Clement (1986). Tropical zonations are not usable due to the scarcity of tropical species. The accumulation rate diagrams (Fig. 2) are based on a combination of paleomagnetic, nannofossil, and planktonic foraminifer datums. In most cases, planktonic foraminifer datums fall on or near the regression lines, with the exception of Globigerina nepenthes, which has its LO consistently below its expected level (Table 2). In this way, these sites are similar to Sites 606 and 607 from $37^{\circ} \mathrm{N}$ and $41^{\circ} \mathrm{N}$, respectively, in the North Atlantic. Zones PL1-PL6 can be recognized at each site (Tables 3,4, and 5), together with several of the zonal markers from the mid-latitude zonation of Weaver and Clement (1986).

\section{Kane Gap Sites 660 and 661}

These two sites were positioned directly east of the Kane Gap deep-water passage on the Sierra Leone Rise. They were chosen to investigate the effects of bottom-current activity and deep-water stagnation in this passage between the southern and northern east Atlantic. Site 660 is located northeast of the northern end of Kane Gap at $4328 \mathrm{~m}$ water depth, and Site 661 is located east of Kane Gap at $4006 \mathrm{~m}$ water depth. Site 660 was drilled to 165 mbsf and terminated in middle Eocene radiolarian ooze. Site 661 was drilled to 296 mbsf and terminated in Upper Cretaceous zeolitic clays.

Although dissolution has had a major effect on the foraminifer faunas, specimens are well preserved in the Pliocene of Site 660 and in the Pliocene and Quaternary of Site 661 (Table 6). Quaternary faunas are poorly preserved to absent at Site 660 , and Miocene specimens were not preserved at all at Site 660 and only poorly preserved at Site 661 . Below the Miocene no specimens of planktonic foraminifers were found at either site. The specimens that were preserved belong to the tropical fauna with common Globigerinoides trilobus, Globigerinoides sacculifer, and Neogloboquadrina dutertrei.

The most reliable stratigraphy for these two sites is provided by the PL zonation of Berggren (1973, 1977a, 1977b) and the mid-latitude zonation of Weaver and Clement (1986). These sites cannot be used to estimate the ages of datums because of the loss of specimens due to dissolution and the low accumulation rates. Nevertheless, most of the datums from these two sites lie on or very close to the regression line indicated on Figure 2.

Most Pliocene zones are recognizable (Tables 7 and 8), but the LO of Globorotalia margaritae is too deep at both sites. At Site 660 only a few specimens of this species were found, presumably because of the strong dissolution. On the other hand, Globigerina nepenthes has its $\mathrm{LO}$ at around its quoted tropical age of $3.9 \mathrm{Ma}$ at both sites. This species may have a synchronous LO in warm tropical sites, although it is diachronous in cooler waters. It also appears to be much more solution resistant than $G$. margaritae.

\section{Equatorial Sites 662-664}

These three sites were selected to retrieve a late Neogene record of climatic variability close to the equator. Sites 662 and 663 lie at 3813 and 3697 mbsf, respectively, and are strongly affected by the Benguela Current, which transports cool water north to the equatorial region. Site 664 lies at 3806 mbsf directly under the area affected by equatorial divergence.

Sites 662 and 663 penetrated to maximum depths of 200 and 152 mbsf, respectively, both terminating in lower Pliocene sediments; Site 664 penetrated a maximum of 296.8 mbsf, terminating in the upper Miocene (Table 9). Sites 662 and 663 show good preservation throughout, and Site 664 shows good preservation from the lower Pliocene to Holocene, with the upper Miocene and lowermost Pliocene sections having poor to moderate preservation (Tables 10-12).

The fauna is tropical, with Globigerinoides ruber, Globigerinoides trilobus, Globigerina decoraperta, and Neogloboquadrina dutertrei/humerosa common to all sites. Some of the holes show an increase in Neogloboquadrina pachyderma and Globorotalia inflata between 0-1 Ma, suggesting an intensification of surface-water cooling during that time.

All three sites contain alternations of calcareous ooze with more siliceous/clay-rich units, particularly from about $2.5 \mathrm{Ma}$ to the present day. These changes reflect the alternation of glacial and interglacial conditions, with the more siliceous sediments containing slightly cooler foraminifer faunas, increased numbers of $N$. pachyderma, and decreased numbers of G. sacculifer.

Unfortunately, all three sites contain numerous slumps and turbidites, which makes age determinations of stratigraphic boundaries difficult. At Site 662 , slumps and turbidites are predominant in the upper $200 \mathrm{~m}$, representing $0-1.3 \mathrm{Ma}$; datums below this level, therefore, should be reliable. Holes drilled at Site 663 and Hole 664B contain too many sediment disturbances to make any accurate age determinations. Hole $664 \mathrm{D}$, however, contains intervals without disturbance between definite slumps at $110.5-118.5$ and $184.3-185.8 \mathrm{mbsf}$, and possible slumps between $52-87.8 \mathrm{mbsf}$.

Table 9 presents the age determinations for Holes $662 \mathrm{~A}$ and 664D. In most cases the datums agree with their published ages, with the usual exception of $G$. margaritae, which has an LO that is 0.19 m.y. too old in Hole $662 \mathrm{~A}$ and $0.38 \mathrm{~m} . \mathrm{y}$. too old in Hole 664D. Hole 662 did not penetrate far enough to reach the $G$. nepenthes datum, but the LO of this species in Hole 664D was only $0.07 \mathrm{~m}$.y. older than its published age.

Globorotalia inflata is rare at both sites and is preceded by the closely related species Globorotalia triangula, which has previously been recorded from Site $366 \mathrm{~A}$ on the Sierra Leone Rise (Krasheninnikov and Pflaumann, 1978). The FO of $G$. inflata corresponds to its expected age only when its range is combined with that of $G$. triangula. This suggests that $G$. triangula may be a tropical ecophenotype of $G$. inflata, rather than a distinct species. 
Table 2. Age and depth determinations of planktonic foraminifer datums in Canary Current Holes 657A, 658A, and 659A.

\begin{tabular}{|c|c|c|c|}
\hline Species & & $\begin{array}{l}\text { Depth } \\
\text { (mbsf) }\end{array}$ & $\begin{array}{l}\text { Age } \\
(\mathrm{Ma})\end{array}$ \\
\hline \multicolumn{4}{|l|}{ Hole $657 \mathrm{~A}$} \\
\hline FO & G. truncatulinoides & $54.7-60.6$ & $1.70-1.95$ \\
\hline LO & G. obliquus & $54.7-60.6$ & $1.70-1.95$ \\
\hline FO & G. inflata & $64.2-65.9$ & $2.15-2.25$ \\
\hline LO & G. miocenica & $64.2-65.9$ & $2.15-2.25$ \\
\hline Reapp. & Pulleniatina & $64.2-65.9$ & $2.15-2.25$ \\
\hline LO & G. puncticulata & $65.9-68.2$ & $2.25-2.35$ \\
\hline LO & G. altispira & $83.2-84.5$ & $2.97-3.05$ \\
\hline LO & S. seminula & $83.2-84.5$ & $2.97-3.05$ \\
\hline LO & Pulleniatina & $130.7-131.6$ & $4.18-4.28$ \\
\hline LO & G. margaritae & $92.7-130.7$ & $3.35-4.18$ \\
\hline FO & G. crassaformis & $131.6-134.6$ & $4.28-4.55$ \\
\hline LO & G. nepenthes & $130.7-131.6$ & $4.18-4.28$ \\
\hline FO & G. puncticulata & ${ }^{a} 131.6-134.6$ & $4.28-4.55$ \\
\hline FO & G. miocenica & $92.7-130.7$ & $3.35-4.18$ \\
\hline FO & G. mangaritae & $144.3-146.1$ & $5.40-5.55$ \\
\hline \multicolumn{4}{|l|}{ Hole $658 \mathrm{~A}$} \\
\hline FO & G. truncatulinoides & $119.7-129.2$ & $1.75-1.90$ \\
\hline LO & G. obliquus & $91.2-100.7$ & $0.62-1.46$ \\
\hline LO & G. miocenica & $155.3-157.7$ & $2.30-2.36$ \\
\hline FO & $G$. inflata & $138.7-148.2$ & $2.04-2.19$ \\
\hline LO & G. puncticulata & $157.7-167.4$ & $2.36-2.48$ \\
\hline LO & G. altispira & $214.9-224.9$ & $2.90-3.00$ \\
\hline LO & S. seminulina & $224.4-233.9$ & $3.00-3.08$ \\
\hline LO & G. margaritae & $290.9-300.4$ & $3.60-3.69$ \\
\hline \multicolumn{4}{|l|}{ Hole $659 \mathrm{~A}$} \\
\hline FO & G. truncatulinoides & $36.3-45.8$ & $1.25-1.60$ \\
\hline LO & G. obliquus & $45.8-64.8$ & $1.60-2.20$ \\
\hline FO & G. inflata & $45.8-64.8$ & $1.60-2.20$ \\
\hline LO & G. exilis & $64.8-65.7$ & $2.20-2.25$ \\
\hline LO & G. miocenica & $64.8-65.7$ & $2.20-2.25$ \\
\hline Reapp. & Pulleniatina & $64.8-65.7$ & $2.20-2.25$ \\
\hline LO & G. puncticulata & $65.7-74.3$ & $2.25-2.50$ \\
\hline LO & G. altispira & $83.8-84.8$ & $2.85-2.90$ \\
\hline LO & S. seminulina & $87.5-90.5$ & $2.95-3.05$ \\
\hline LO & Pulleniatina & $93.3-102.8$ & $3.15-3.45$ \\
\hline LO & G. margaritae & $102.8-112.3$ & $3.45-3.72$ \\
\hline FO & G. crassaformis & $125.5-131.3$ & $4.20-4.40$ \\
\hline LO & G. nepenthes & $125.5-131.3$ & $4.20-4.40$ \\
\hline FO & G. puncticulata & $125.5-131.3$ & $4.20-4.40$ \\
\hline FO & G. miocenica & $112.3-116.0$ & $3.72-3.85$ \\
\hline $\mathrm{FO}$ & G. margaritae & $159.8-182.8$ & $6.20-8.10$ \\
\hline LO & G. dehiscens & $188.3-197.8$ & $8.20-10.50$ \\
\hline FO & N. humerosa & $159.8-182.8$ & $8.20-10.50$ \\
\hline FO & N. acostaensis & $159.8-182.8$ & $8.20-10.50$ \\
\hline
\end{tabular}

${ }^{\mathrm{a}}$ In slump.

\section{Sierra Leone Rise Sites 665-668}

These four sites make up a depth transect down the southern flank of the Sierra Leone Rise from Site 668 at 2700 mbsf to Site 665 at 4750 mbsf. One of the objectives of this transect was to assess dissolution gradients in the eastern Atlantic, using sites which show varying levels of carbonate preservation.

The most useful stratigraphy is again a combination of the PL zonation of Berggren (1973, 1977a, 1977b) and the zonal markers of Weaver and Clement (1986). The large number of turbidites at Site 666 preclude an assessment of the ages of zonal markers in that site, and the short interval cored at Site 668 did not allow ages to be assessed here. Sites 665 and 667 , however, provided useful stratigraphic information, which is summarized in Table 13.

Sites 665 and 666 lie below $4000 \mathrm{~m}$ water depth and contain moderately to poorly preserved faunas (Tables 14 and 15). Good preservation is limited to the numerous turbidites and transported sediments at Site 666. Sediments older than 3.8 $\mathrm{Ma}$ at Site 665 and $3.9 \mathrm{Ma}$ at Site 666 consist of red clay, barren of planktonic foraminifers.

Site 667 , taken from 3535 mbsf, penetrated a maximum of $309.2 \mathrm{~m}$, terminating in upper Oligocene nannofossil ooze. Planktonic foraminifers, which are present throughout Site 667 , are moderately preserved in the Miocene and Oligocene, with some poorly preserved samples in the lower part of the sequence (Table 16). They are well preserved through the Pliocene and moderately to well preserved in the Quaternary (Table 16).

Site 668 was positioned on top of the Sierra Leone Rise at a water depth of $2704 \mathrm{~m}$. It produced a complete Quaternary sequence with well-preserved planktonic foraminifers (Table 17).

The faunas from all these sites are similar and are composed of tropical species that include Globigerinoides trilobus, Globigerinoides ruber, Globigerinoides sacculifer, and Neogloboquadrina dutertrei/humerosa. The Miocene section of Site 668 contains numerous Globoquadrina altispira, Globoquadrina venezuelana, Globoquadrina dehiscens, and Globorotalia mayeri.

The FO of Globorotalia truncatulinoides is not reliable at Site 665 , probably because of its rare occurrence in tropical areas. Globorotalia inflata is also unreliable at Site 667 , probably for the same reasons; it does, however, have an FO in Site 665 at the expected age. The other stratigraphic markers have FOs and LOs in line with their published ages, including Globorotalia margaritae and Globigerina nepenthes.

\section{DISCUSSION}

Throughout the early years of the Deep Sea Drilling Project, planktonic foraminifer stratigraphies for the Neogene were developed and applied to various sites throughout the world's oceans. It was always appreciated that many species were limited latitudinally, but the diachronism of the FO and LO of species was difficult to document (Sarnthein et al., 1982). With the advent of the hydraulic piston corer (HPC), undisturbed Neogene cores suitable for paleomagnetic stratigraphy have been drilled and have allowed independent testing of the stratigraphic ranges of species.

Hodell and Kennett (1986) and Weaver and Clement (1986, 1987) have shown that diachronism commonly characterizes planktonic foraminifer datums. Thus, a species such as $G$. margaritae can have an LO $1 \mathrm{~m} . \mathrm{y}$. earlier in cooler water areas than in the subtropics, even though the species may be common throughout its range in both areas. We have, therefore, approached the foraminifer stratigraphy of these tropical sites with some caution.

Incomplete paleomagnetic records have limited our age estimates for several sites, and we produced their accumulation rate curves by combining nannofossil, planktonic foraminifer, diatom, and magnetic data. Some sites contained slumps and turbidites that we had to account for, except at Sites 663 and 666, where reworking was on such a large scale that accumulation rate curves could not be drawn. Small discrepancies between published and observed ages may be due to undetected changes in accumulation rates, but the larger discrepancies must be regarded as real.

Most of the age information given by Berggren et al. (1985) was derived in tropical or subtropical areas and would, therefore, be expected to be applicable to the sites examined here. Sites 657,658 , and 659 , however, lie under the cool Canary Current; and Sites 662, 663, and 664 lie under derivatives of the Benguela Current. Thus, these sites are subject to 
Table 3. Distribution of planktonic foraminifers, Hole 657A.

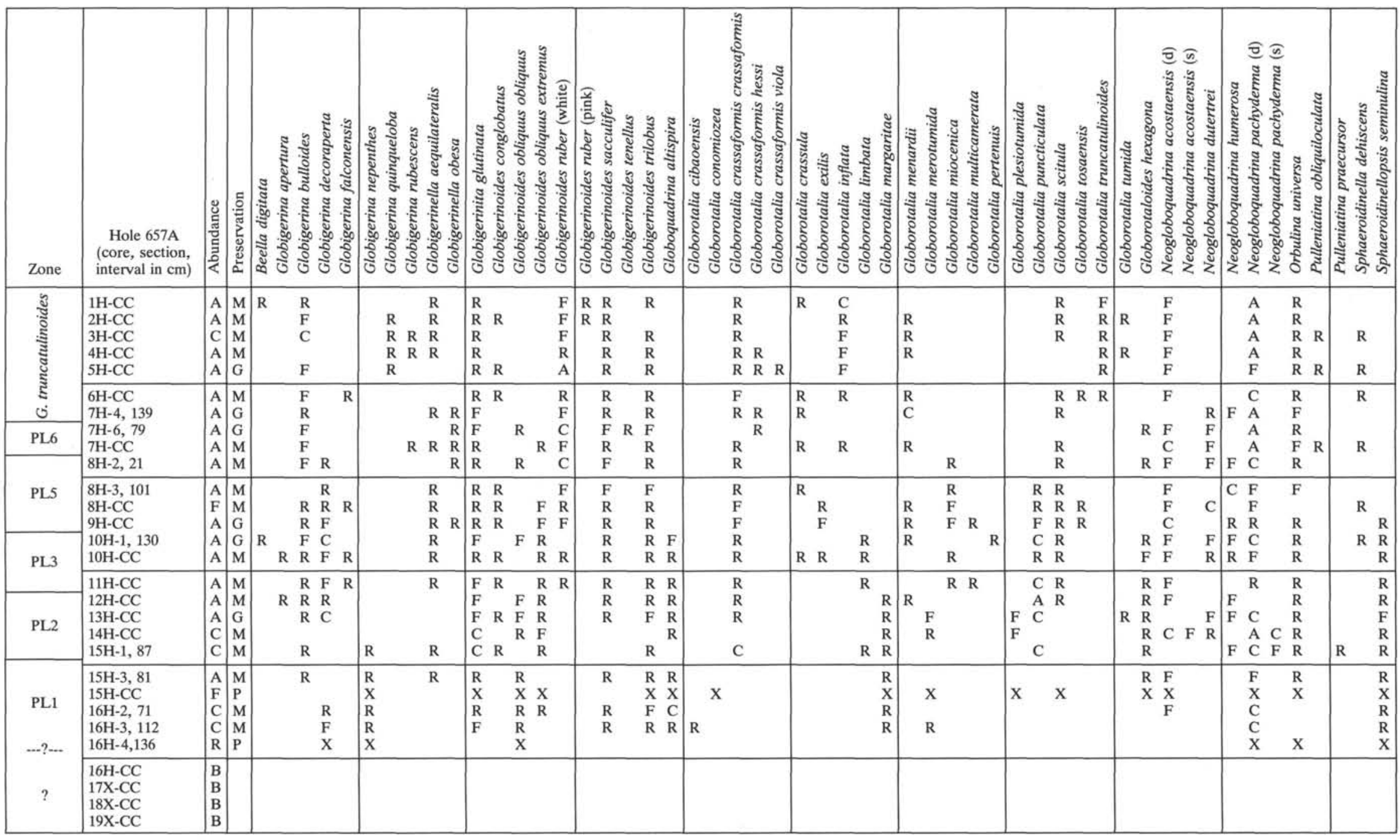

Note: $\mathrm{R}=<3 \%, \mathrm{~F}=3 \%-15 \%, \mathrm{C}=15 \%-30 \%, \mathrm{~A}=>30 \%$, and $\mathrm{X}=$ present but no abundance estimate. 


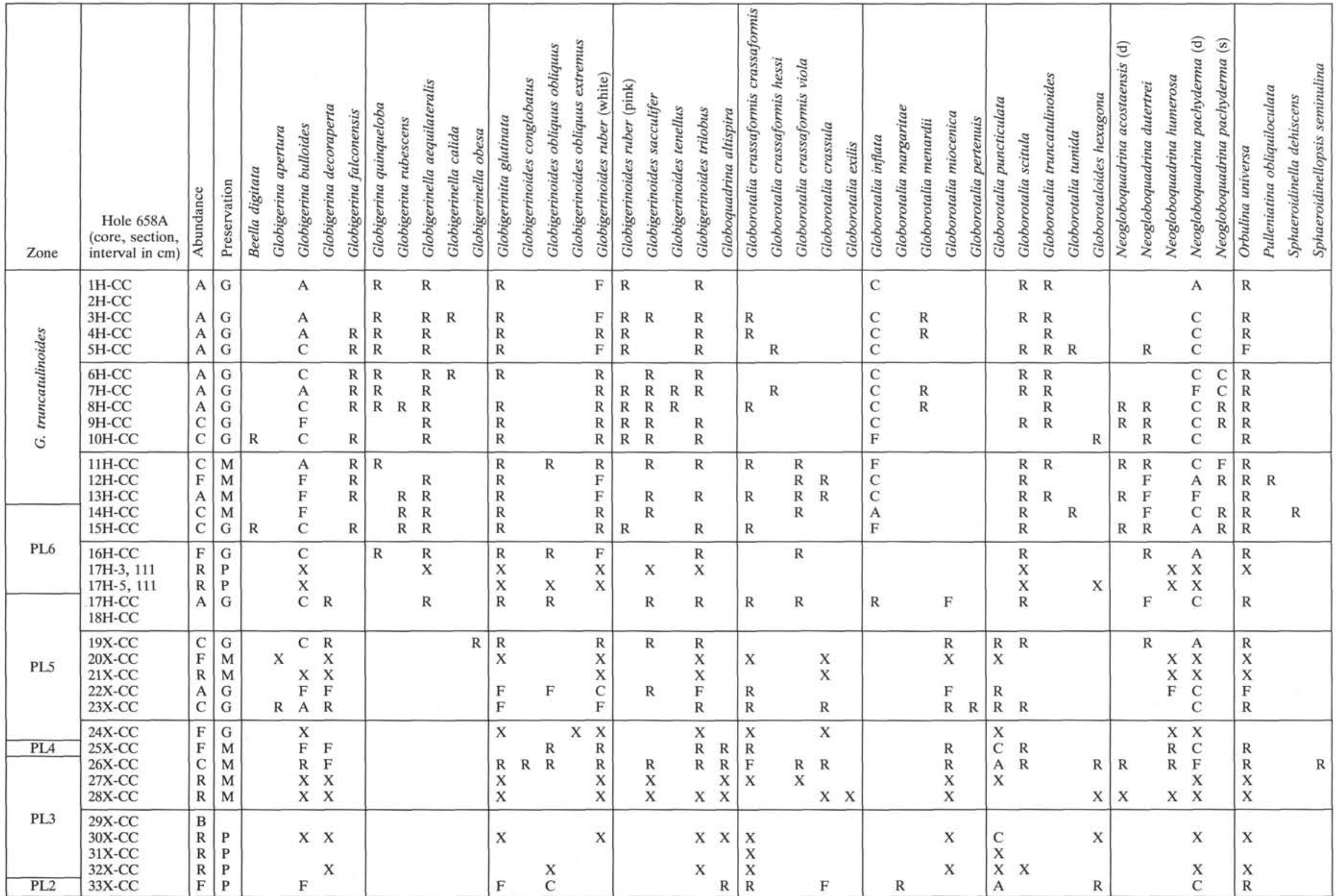


Table 5. Distribution of planktonic foraminifers, Hole 658A.

\begin{tabular}{|c|c|c|c|c|c|c|c|c|c|c|c|c|c|c|c|}
\hline Zone & $\begin{array}{c}\text { Hole 659A } \\
\text { (core, section, } \\
\text { interval in cm) }\end{array}$ & & 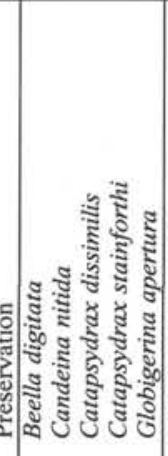 & 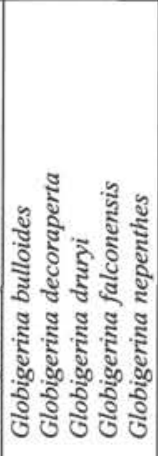 & 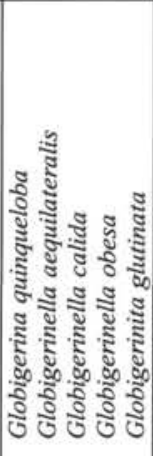 & 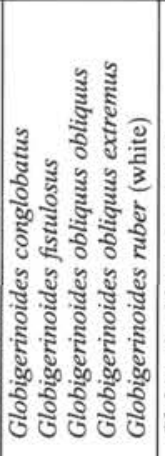 & 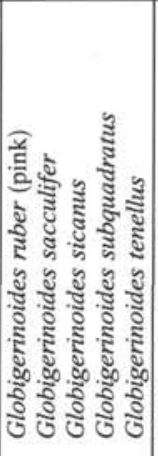 & 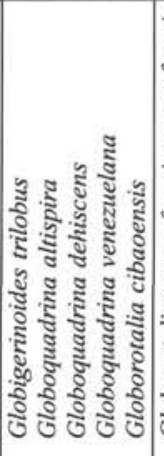 & 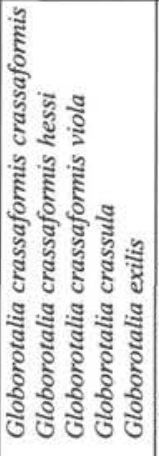 & 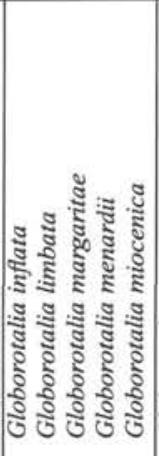 & 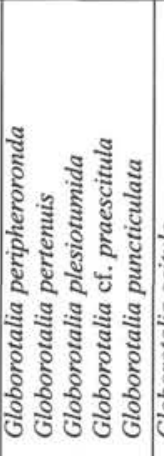 & 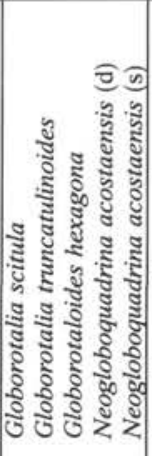 & 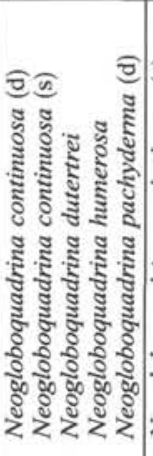 & 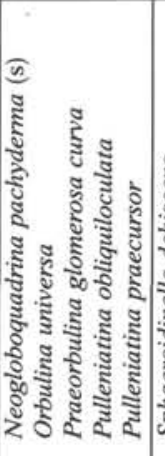 & 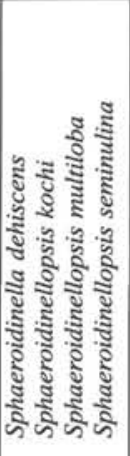 \\
\hline $\begin{array}{c}\text { G. trun- } \\
\text { catuli- } \\
\text { noides } \\
-\cdots ?-- \\
----\end{array}$ & $\begin{array}{l}1 \mathrm{H}-\mathrm{CC} \\
2 \mathrm{H}-\mathrm{CC} \\
3 \mathrm{H}-\mathrm{CC} \\
4 \mathrm{H}-\mathrm{CC} \\
5 \mathrm{H}-\mathrm{CC} \\
\end{array}$ & \begin{tabular}{|l|l|}
$\mathrm{A}$ & $\mathrm{G}$ \\
$\mathrm{A}$ & $\mathrm{G}$ \\
$\mathrm{A}$ & $\mathrm{G}$ \\
$\mathrm{A}$ & $\mathrm{G}$ \\
$\mathrm{A}$ & $\mathrm{G}$ \\
\end{tabular} & s. & $\begin{array}{|ll|}\mathrm{C} & \\
\mathrm{C} & \\
\mathrm{C} & \mathrm{R} \\
\mathrm{C} & \\
\mathrm{C} & \\
\end{array}$ & $\begin{array}{|llll|}\text { R } & \text { R } & \text { R } & \text { R } \\
\text { R } & \text { R } & \text { R } & \text { R } \\
\text { R } & \text { R } & & \text { F } \\
\text { R } & \text { R } & & \text { F } \\
\text { R } & & \text { R } \\
\end{array}$ & \begin{tabular}{l|}
$\mathrm{F}$ \\
$\mathrm{F}$ \\
$\mathrm{F}$ \\
$\mathrm{C}$ \\
$\mathrm{C}$
\end{tabular} & $\begin{array}{|lll|}\text { R } & \text { R } & \\
\text { R } & \text { R } & \\
\text { R } & \text { R } & \\
\text { R } & \text { R } & \\
\text { R } & \\
\text { R } & \text { R } \\
\end{array}$ & $\begin{array}{l}R \\
R \\
R \\
R \\
R \\
\end{array}$ & \begin{tabular}{|lll}
$\mathrm{R}$ & & \\
& $\mathrm{R}$ & $\mathrm{R}$ \\
$\mathrm{R}$ & \\
$\mathrm{R}$ & \\
\end{tabular} & \begin{tabular}{|ll}
$\mathrm{C}$ & \\
$\mathrm{C}$ & $\mathrm{R}$ \\
$\mathrm{C}$ & $\mathrm{R}$ \\
$\mathrm{F}$ & \\
$\mathrm{F}$ & $\mathrm{R}$ \\
\end{tabular} & & \begin{tabular}{|lll}
$R$ & $R$ \\
$R$ & $F$ \\
$R$ & $R$ \\
$R$ & $R$ & $R$ \\
$R$ & $R$ \\
\end{tabular} & $\begin{array}{ll}\mathrm{R} & \mathrm{C} \\
\mathrm{F} & \mathrm{A} \\
\mathrm{F} & \mathrm{C} \\
\mathrm{F} & \mathrm{C} \\
\mathrm{F} & \mathrm{C} \\
\end{array}$ & $\begin{array}{ll}\mathrm{R} & \\
\mathrm{F} & \\
\mathrm{F} & \\
\mathrm{F} & \mathrm{R} \\
\mathrm{F} & \mathrm{R} \\
\end{array}$ & $\begin{array}{l}\mathrm{R} \\
\mathrm{R} \\
\end{array}$ \\
\hline PL5 & $\begin{array}{l}6 \mathrm{H} \\
7 \mathrm{H}-\mathrm{CC} \\
8 \mathrm{H}-1,36 \\
8 \mathrm{H}-\mathrm{CC} \\
9 \mathrm{H}-\mathrm{CC} \\
\end{array}$ & \begin{tabular}{|l|l|}
$\mathrm{A}$ & $\mathrm{G}$ \\
$\mathrm{A}$ & $\mathrm{G}$ \\
$\mathrm{A}$ & $\mathrm{G}$ \\
$\mathrm{A}$ & $\mathrm{M}$ \\
\end{tabular} & & $\begin{array}{llll}\text { C } & & \\
\text { R } & \text { C } & \text { R } \\
\text { F } & \text { F } & \text { R } \\
\text { F } & \text { F } & \\
\end{array}$ & 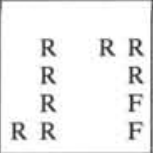 & 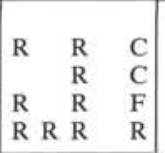 & $\begin{array}{l}\mathrm{R} \\
\mathrm{R} \\
\mathrm{R} \\
\mathrm{R}\end{array}$ & $\begin{array}{l}\mathrm{R} \\
\mathrm{R} \\
\mathrm{R} \\
\mathrm{R}\end{array}$ & 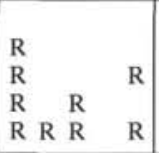 & $\begin{array}{l}\mathrm{F} \\
\mathrm{F} \\
\mathrm{R}\end{array}$ & $\begin{array}{l}\mathrm{R} \\
\mathrm{R}\end{array}$ & $\begin{array}{l}\mathrm{F} \\
\mathrm{R} \\
\mathrm{R}\end{array}$ & $\begin{array}{lll}F & C \\
& R & C \\
C & F \\
F & R & F\end{array}$ & $\begin{array}{r}\mathrm{F} \\
\mathrm{R} \\
\mathrm{R} \\
\mathrm{R} \\
\mathrm{R}\end{array}$ & $\begin{array}{l}\mathrm{R} \\
\mathrm{R} \\
\mathrm{R}\end{array}$ \\
\hline PL4 & $\begin{array}{l}10 \mathrm{H}-1,101 \\
10 \mathrm{H}-3,70 \\
10 \mathrm{H}-5,70 \\
10 \mathrm{H}-\mathrm{CC} \\
11 \mathrm{H}-\mathrm{CC} \\
\end{array}$ & \begin{tabular}{|l|l|}
$\mathrm{A}$ & $\mathrm{G}$ \\
$\mathrm{A}$ & $\mathrm{G}$ \\
$\mathrm{A}$ & $\mathrm{G}$ \\
$\mathrm{A}$ & $\mathrm{G}$ \\
$\mathrm{A}$ & $\mathrm{G}$ \\
\end{tabular} & 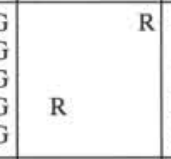 & $\begin{array}{lll}\text { R } & \text { R } \\
& \text { F } \\
\text { R } & \text { C } \\
\text { F } & \text { F } \\
\text { F } & \text { C } \\
\end{array}$ & $\begin{array}{lr}\mathrm{R} & \mathrm{R} \\
\mathrm{R} & \mathrm{R} \\
\mathrm{R} & \mathrm{R} \\
\mathrm{R} & \mathrm{R} \\
\mathrm{R} & \mathrm{R} \\
\end{array}$ & \begin{tabular}{llll|}
$\mathrm{R}$ & $\mathrm{F}$ & $\mathrm{R}$ & $\mathrm{C}$ \\
& $\mathrm{F}$ & $\mathrm{R}$ & $\mathrm{F}$ \\
$\mathrm{R}$ & & $\mathrm{F}$ & $\mathrm{F}$ \\
$\mathrm{R}$ & $\mathrm{R}$ & $\mathrm{F}$ \\
$\mathrm{R}$ & $\mathrm{F}$ & $\mathrm{F}$ \\
\end{tabular} & $\begin{array}{l}\mathrm{F} \\
\mathrm{R} \\
\mathrm{R} \\
\mathrm{R} \\
\mathrm{R}\end{array}$ & $\begin{array}{lll}F & F \\
R & R \\
F & R \\
R & F \\
R & F \\
\end{array}$ & \begin{tabular}{lrll|}
$R$ & R & F & R \\
$\mathrm{R}$ & & R \\
$\mathrm{R}$ & & $\mathrm{R}$ & $\mathrm{R}$ \\
$\mathrm{R}$ & $\mathrm{F}$ & $\mathrm{R}$ & $\mathrm{R}$ \\
$\mathrm{R}$ & & & \\
\end{tabular} & 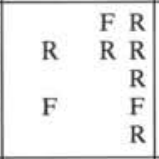 & \begin{tabular}{l|l}
$R$ & \\
$C$ & \\
$C$ & \\
$F$ & \\
$R$ &
\end{tabular} & $\begin{array}{|ll|}\mathrm{R} & \mathrm{R} \\
& \mathrm{RF} \\
\mathrm{R} & \mathrm{R} \\
\mathrm{R} & \mathrm{R} \mathrm{R} \\
\mathrm{R} & \mathrm{R} \\
\end{array}$ & \begin{tabular}{lrr|}
$R$ & $C$ & $R$ \\
& C \\
$C$ & $R$ & $R$ \\
$C$ & $R$ \\
$R$ & $R$ \\
& $R$ \\
\end{tabular} & $\begin{array}{l}\mathrm{R} \\
\mathrm{R} \\
\mathrm{R} \\
\mathrm{R} \\
\mathrm{R} \\
\end{array}$ & $\begin{array}{l}\mathrm{R} \\
\mathrm{R}\end{array}$ \\
\hline PL2 & $\begin{array}{l}12 \mathrm{H}-\mathrm{CC} \\
13 \mathrm{H}-\mathrm{CC} \\
14 \mathrm{H}-3,74 \\
14 \mathrm{H}-\mathrm{CC} \\
15 \mathrm{H}-\mathrm{CC} \\
\end{array}$ & \begin{tabular}{|l|l}
$\mathrm{A}$ & $\mathrm{G}$ \\
$\mathrm{A}$ & $\mathrm{G}$ \\
$\mathrm{A}$ & $\mathrm{G}$ \\
$\mathrm{A}$ & $\mathrm{G}$ \\
$\mathrm{A}$ & $\mathrm{G}$ \\
\end{tabular} & 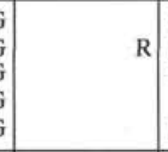 & 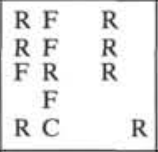 & $\begin{array}{lr}\mathrm{R} & \mathrm{R} \\
\mathrm{R} & \mathrm{R} \\
\mathrm{R} & \mathrm{R} \\
\mathrm{R} & \mathrm{R} \mathrm{R} \\
\mathrm{R} & \mathrm{R} \\
\end{array}$ & $\begin{array}{|llll|}\mathrm{R} & \mathrm{R} & \mathrm{R} & \mathrm{R} \\
\mathrm{R} & \mathrm{F} & \mathrm{F} \\
\mathrm{R} & & \mathrm{F} \\
\mathrm{R} & \mathrm{F} & \mathrm{F} \\
& \text { F } & \mathrm{R} \\
\end{array}$ & $\begin{array}{l}\mathrm{F} \\
\mathrm{R} \\
\mathrm{F} \\
\mathrm{R} \\
\mathrm{R}\end{array}$ & $\begin{array}{ll}F & R \\
R & F \\
F & R \\
R & F \\
R & R \\
\end{array}$ & 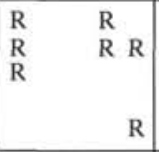 & $\begin{array}{lll}\text { F } & & R \\
\text { F } & & R \\
\text { F } & R & \\
\text { R } & R & \\
\text { F } & R & \\
\end{array}$ & $\begin{array}{lll}R^{R} & & C \\
R & R\end{array}$ & \begin{tabular}{ll}
$\mathrm{R}$ & $\mathrm{R}$ \\
$\mathrm{R}$ & $\mathrm{R}$ \\
$\mathrm{R}$ & $\mathrm{R}$ \\
$\mathrm{R}$ & \multicolumn{2}{r}{$\mathrm{R}$} \\
$\mathrm{R}$ & $\mathrm{R}$ \\
\end{tabular} & 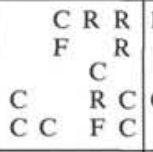 & $\begin{array}{rl}R & R \\
R \\
R \\
\text { C R }\end{array}$ & 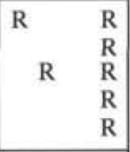 \\
\hline PL1/M13 & $\begin{array}{l}16 \mathrm{H}-\mathrm{CC} \\
17 \mathrm{H}-\mathrm{CC} \\
18 \mathrm{H}-\mathrm{CC} \\
19 \mathrm{H}-\mathrm{CC} \\
20 \mathrm{H}-3,104\end{array}$ & \begin{tabular}{|l|l|}
$A$ & $M$ \\
$A$ & $G$ \\
$C$ & \\
$C$ & $M$ \\
\end{tabular} & a. & $\begin{array}{l}\mathrm{R} \\
\mathrm{R}\end{array}$ & $\begin{array}{lll}R & R & R \\
& R & R\end{array}$ & $\begin{array}{l}\text { R R } \\
\text { F F } \\
\text { R }\end{array}$ & $\begin{array}{l}\mathrm{R} \\
\mathrm{R} \\
\mathrm{R}\end{array}$ & $\begin{array}{|llll|}\text { R } & \text { R } & & \\
\text { R } & \text { F } & & \\
& & \\
& & \\
\text { R } & \text { R } & \text { C } & \\
\end{array}$ & & $\begin{array}{l}\text { R R } \\
\text { F }\end{array}$ & R & $\begin{array}{lll}\mathrm{R} & & \mathrm{CF} \\
& & \mathrm{C} \\
& & \\
\mathrm{R} & \mathrm{R} & \\
\end{array}$ & $\begin{array}{lll}\text { C F } & \text { F } & \text { C } \\
\text { C } & \text { F } & \text { C } \\
& & \\
\text { F } & & \end{array}$ & $\begin{array}{l}F_{\mathrm{R}} \\
\mathrm{F}\end{array}$ & $\begin{array}{l}\mathrm{R} \\
\mathrm{R}\end{array}$ \\
\hline $\begin{array}{l}\text { P. glo- } \\
\text { merosa }\end{array}$ & $\begin{array}{l}20 \mathrm{H}-\mathrm{CC} \\
21 \mathrm{X}-\mathrm{CC} \\
22 \mathrm{X}-\mathrm{CC} \\
23 \mathrm{X}-\mathrm{CC} \\
24 \mathrm{X}-\mathrm{CC}\end{array}$ & \begin{tabular}{|l|l}
$\mathrm{C}$ & $\mathrm{M}$ \\
$\mathrm{C}$ & $\mathrm{M}$ \\
$\mathrm{R}$ & $\mathrm{P}$ \\
$\mathrm{B}$ & \\
$\mathrm{A}$ & $\mathrm{M}$
\end{tabular} & & 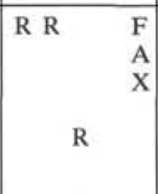 & $R$ & $\begin{array}{l}\mathrm{F} \\
\mathrm{R}\end{array}$ & $\begin{array}{l}\text { R } \\
\text { R R R }\end{array}$ & 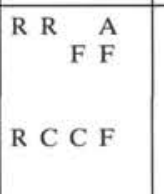 & & $\begin{array}{ll}\mathrm{R} & \mathrm{R} \\
\mathrm{R} & \end{array}$ & A & $\begin{array}{l}\mathrm{R} \\
\mathrm{R}\end{array}$ & & $\begin{array}{l}\mathrm{R} \\
\mathrm{R}\end{array}$ & $\begin{array}{ll}\mathrm{R} & \mathrm{C} \\
\mathrm{R} & \mathrm{C} \\
\mathrm{X} & \end{array}$ \\
\hline $\begin{array}{l}\text { C. stain- } \\
\text { forthi }\end{array}$ & $\begin{array}{l}25 \mathrm{X}-\mathrm{CC} \\
26 \mathrm{X}-\mathrm{CC} \\
27 \mathrm{X}-\mathrm{CC} \\
28 \mathrm{X}-\mathrm{CC} \\
29 \mathrm{X}-\mathrm{CC}\end{array}$ & \begin{tabular}{|l|l}
$\mathrm{F}$ & $\mathrm{P}$ \\
$\mathrm{B}$ & \\
$\mathrm{R}$ & $\mathrm{P}$ \\
$\mathrm{B}$ & - \\
$\mathrm{B}$ & \\
\end{tabular} & R R & & & & & $\begin{array}{r}\text { F F R } \\
\text { X }\end{array}$ & & & A & & $x$ & $R$ & \\
\hline
\end{tabular}


Table 6. Age and depth determinations of planktonic foraminifer datums in Kane Gap Holes 660A and 661A.

\begin{tabular}{llll}
\hline Species & & $\begin{array}{c}\text { Depth } \\
\text { (mbsf) }\end{array}$ & $\begin{array}{c}\text { Age } \\
\text { (Ma) }\end{array}$ \\
\hline $\begin{array}{l}\text { Hole 660A } \\
\text { FO }\end{array}$ & G. truncatulinoides & $39.8-44.0$ & $1.95-2.25$ \\
LO & G. obliquus & $20.8-30.3$ & a $0.80-1.30$ \\
FO & G. inflata & $39.8-44.0$ & $1.95-2.25$ \\
LO & G. exilis & $44.0-46.7$ & $2.25-2.42$ \\
LO & G. miocenica & $44.0-46.7$ & $2.25-2.42$ \\
Reapp. & Pulleniatina & $39.8-41.6$ & $1.90-2.07$ \\
LO & G. puncticulata & $44.0-46.7$ & $2.25-2.42$ \\
LO & G. altispira & $53.8-56.6$ & $2.87-3.08$ \\
LO & S. seminulina & $56.6-58.8$ & $3.08-3.24$ \\
LO & G. crassula & $56.6-58.8$ & $3.08-3.24$ \\
LO & Pulleniatina spp. & $58.8-68.3$ & $3.24-3.84$ \\
FO & G. miocenica & $56.6-58.8$ & $3.08-3.24$ \\
LO & G. mangaritae & $68.3-69.4$ & $3.84-3.90$ \\
FO & G. crassaformis & $69.4-72.1$ & $3.90-4.55$ \\
LO & G. nepenthes & $69.4-72.1$ & $3.90-4.55$ \\
LO & N. pachyderma (s) & $69.4-72.1$ & $3.90-4.55$ \\
FO & G. puncticulata & $58.8-68.3$ & $3.24-3.84$
\end{tabular}

\begin{tabular}{llrl} 
Hole $661 \mathrm{~A}$ & & & \\
FO & G. truncatulinoides & $1.6-11.1$ & $0.10-0.67$ \\
LO & G. obliquus & $11.1-20.6$ & $0.67-1.30$ \\
LO & G. exilis & $31.5-34.5$ & $1.96-2.24$ \\
FO & G. inflata & $30.1-31.5$ & $1.85-1.96$ \\
LO & G. miocenica & $31.5-34.5$ & $1.96-2.24$ \\
Reapp. & Pulleniatina & $31.5-34.5$ & $1.96-2.24$ \\
LO & G. puncticulata & $31.5-34.5$ & $1.96-2.24$ \\
LO & G. altispira & $41.0-44.0$ & $2.70-2.87$ \\
LO & S. seminulina & $44.0-47.0$ & $2.87-3.05$ \\
LO & Pulleniatina spp. & $49.1-58.6$ & $3.20-3.75$ \\
LO & G. mangaritae & $58.6-59.9$ & $3.74-3.80$ \\
FO & G. crassaformis & $59.9-62.5$ & $3.80-4.00$ \\
LO & G. nepenthes & $59.9-62.5$ & $3.80-4.00$ \\
FO & G. puncticulata & $59.9-62.5$ & $3.80-4.00$ \\
FO & G. miocenica & $49.1-58.6$ & $3.18-3.74$ \\
FO & G. margaritae & $65.1-68.1$ & $4.60-5.38$ \\
LO & G. dehiscens & $65.1-68.1$ & $4.60-5.38$ \\
\hline
\end{tabular}

${ }^{a}$ Probably reworked.

cooler influences that have limited the stratigraphic ranges of some of the tropical planktonic foraminifers.

The LOs of Globorotalia margaritae and G. nepenthes offer good examples of this problem. They have both been used extensively in previous zonal schemes, and G. margaritae in particular is common throughout its range from the tropics to at least $50^{\circ} \mathrm{N}$ (Weaver and Clement, 1986). Globorotalia margaritae has a quoted $\mathrm{LO}$ of $3.4 \mathrm{Ma}$, and $G$. nepenthes has a quoted LO of 3.9 Ma (Berggren et al., 1985). Table 18 shows that $G$. margaritae has a LO of 3.4 Ma only at Site 667 , the only warm tropical site which has no significant dissolution.

Although Sites 660 and 661 are not influenced by the cool waters of the Canary and Benguela currents, they have suffered strong dissolution. This has affected the distribution of $G$. margaritae but not the distribution of $G$. nepenthes, which is more dissolution resistant. Globigerina nepenthes has an LO of 3.9 Ma at Sites 660,661, and 667; it has an earlier LO at all sites affected by the Canary or Benguela currents, however.

Of the other species used by Berggren in his PL zonation, Globorotalia truncatulinoides and G. obliquus are not reliable in the Leg 108 sites. The FO of $G$. truncatulinoides frequently has its FO well above its published age of $1.9 \mathrm{Ma}$. There is no apparent pattern to its distribution, except that it is seldom very common and its evolution from G. tosaensis is not seen. Likewise, G. obliquus often occurs well above its expected LO (1.8 Ma) in both warm and cool tropical sites.

The LOs of Globorotalia miocenica, Globoquadrina altispira, and Sphaeroidinellopsis seminulina all give very accurate datums at both warm and cool sites, with the only exception being the latter two datums at Site 667 . In fact, these two datums would suggest an alternative accumulation rate curve for this site (Fig. 2), but there appears to be considerable reworking and FOs are only regarded as accurate below 2.3 Ma.

Berggren et al. (1985) list a number of other Pliocene datums, the most useful of which appear in Table 18. Globorotalia exilis is less common and less reliable in the cooler sites, unlike $G$. miocenica, which is both common and reliable in all sites. The temporary disappearance of species of Pulleniatina between 3.3 and 2.2 Ma gives two very useful datums, which are generally accurate, except at Site 657 where this genus is rare. The FO of $G$. miocenica has been difficult to determine because of the difficulty in distinguishing this species from Globorotalia pseudomiocenica, from which it has gradually evolved (Bolli and Saunders, 1985).

We have been able to use some of the datums from the mid-latitude zonation of Weaver and Clement (1986), especially the FOs of Globorotalia puncticulata and G. inflata. Globorotalia inflata is generally rare in tropical sites because of its preference for cooler intermediate waters. Nevertheless, it provides a useful datum at all but Site 667 , where it is absent in the early part of its range.

Weaver and Clement (1986) noted a short interval between the LO of $G$. puncticulata and the FO of $G$. inflata when neither species was present. This interval is also present in the Leg 108 sites; therefore, the LO of G. puncticulata at $2.3 \mathrm{Ma}$ provides a further useful datum. The FO of G. puncticulata (4.15 Ma) provides a consistent datum in all but Kane Gap Sites 660 and 661 , where dissolution is strong.

Globorotalia puncticulata generally appears at the same time as Globorotalia crassaformis in the north and equatorial Atlantic, but it appears somewhat earlier in the Pacific. The ages of the FOs of $G$. inflata and $G$. puncticulata agree closely with their ages in the Mediterranean (Rio et al., 1984) and facilitate direct comparisons with the Mediterranean zones of Iaccarino and Salvatorini (1982).

The late Miocene represents much more of a stratigraphic problem than the Pliocene, since there are few sites with good paleomagnetic control and few reliable zonal markers. Sites 659,664 , and 667 all contain late Miocene planktonic foraminifers, but there is no paleomagnetic control in any of these, and the accumulation rate curves are based mainly on nannofossil data.

Berggren et al. (1983) created a zonal scheme for the Miocene using the LO of Globoquadrina dehiscens and the FOs of Globorotalia margaritae, Globorotalia conomiozea, and Neogloboquadrina acostaensis as late Miocene markers. The age of the $G$. margaritae datum appears to be slightly variable in the Leg 108 sites (Table 18), but this is the only datum in the latest Miocene/early Pliocene that can be recognized. The LO of $G$. dehiscens is very unreliable, mainly because this species is rare to absent at the end of its range, and the $G$. conomiozea datum cannot be used because of the absence of this species.

Neogloboquadrina acostaensis occurs commonly, but in Hole 659A its FO is not seen because of two lost cores. Hole 664D did not penetrate far enough to reach this level, and in Hole 667 it has an FO at 8.6-10.3 Ma. This is rather broad due to the low deposition rate, but it does overlap the expected age of $10.2 \mathrm{Ma}$. The $N$. acostaensis datum was used by Banner and Blow (1965) and subsequent authors (including Bolli and 
Table 7. Distribution of planktonic foraminifers, Hole $660 \mathrm{~A}$.

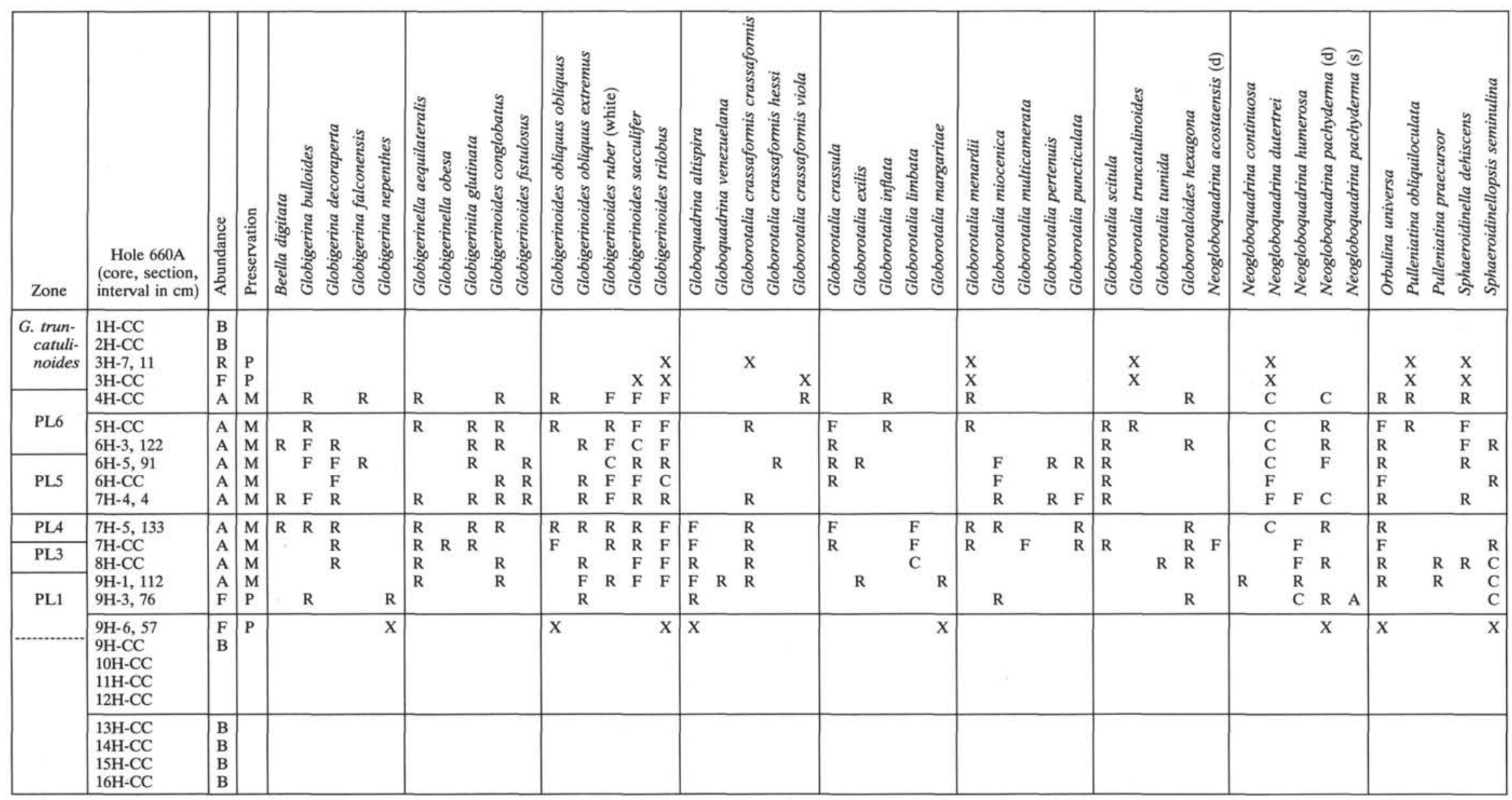


Table 8. Distribution of planktonic foraminifers, Hole 661A

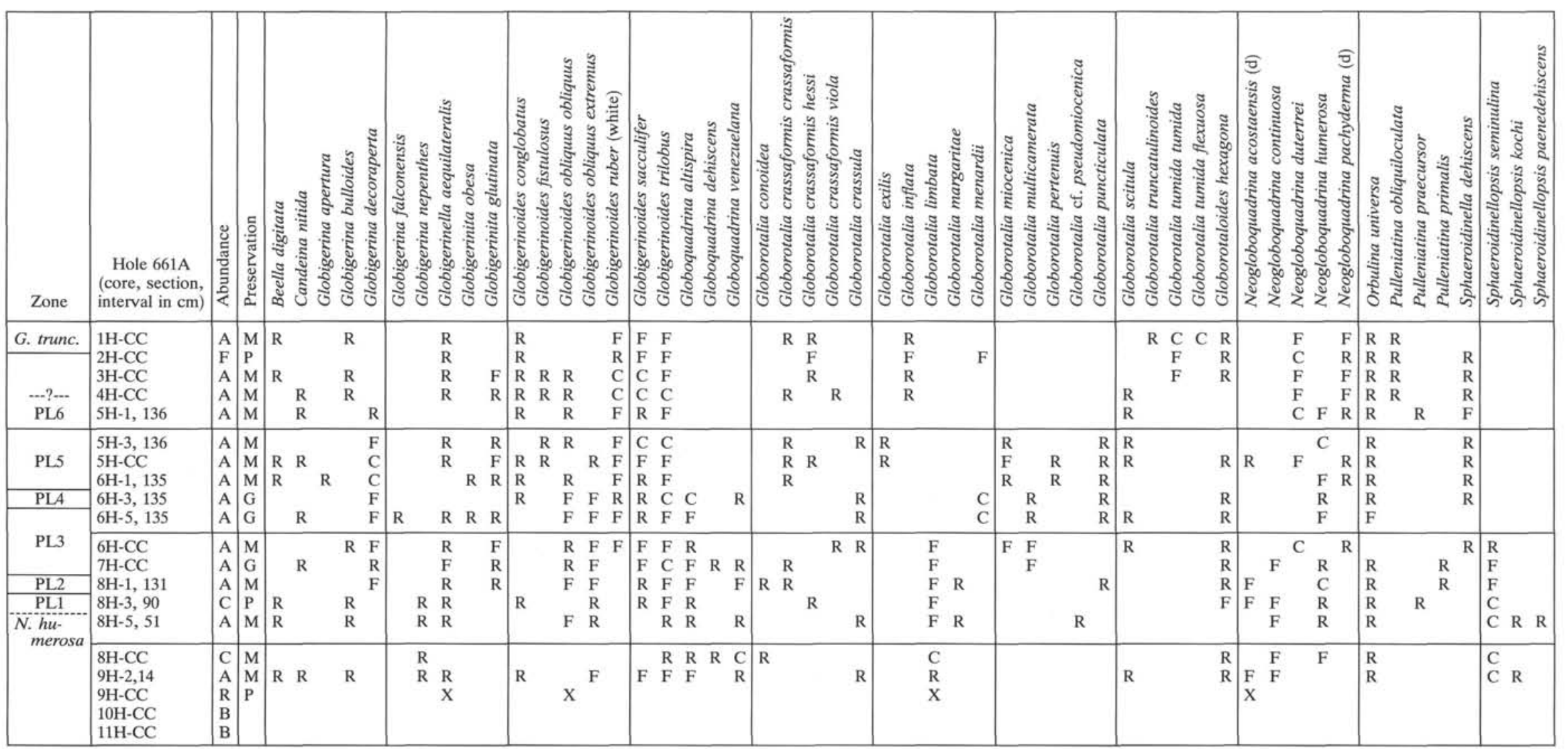


Table 9. Age and depth determinations of planktonic foraminifer datums in Benguela Current Holes 662A and 664D.

\begin{tabular}{|c|c|c|c|}
\hline Species & & $\begin{array}{l}\text { Depth } \\
\text { (mbsf) }\end{array}$ & $\begin{array}{l}\text { Age } \\
\text { (Ma) }\end{array}$ \\
\hline \multicolumn{4}{|c|}{ Hole $662 \mathrm{~A}$} \\
\hline LO & G. obliquus extremus & $117.2-126.7$ & $1.73-1.94$ \\
\hline FO & G. truncatulinoides & $82.4-107.7$ & 1.52 \\
\hline FO & G. inflata & $126.7-136.0$ & $1.94-2.14$ \\
\hline LO & G. exilis & $140.5-145.7$ & $2.24-2.36$ \\
\hline LO & G. miocenica & $137.5-140.5$ & $2.18-2.24$ \\
\hline Reapp. & Pulleniatina & $137.5-140.5$ & $2.18-2.24$ \\
\hline LO & G. puncticulata & $137.5-140.5$ & $2.18-2.24$ \\
\hline LO & G. altispira & $166.8-168.4$ & $2.86-2.90$ \\
\hline LO & S. seminulina & $168.4-174.2$ & $2.90-3.04$ \\
\hline LO & Pulleniatina spp. & $183.7-193.2$ & $3.26-3.49$ \\
\hline LO & G. margaritae & $197.5-200.5$ & $3.59-3.66$ \\
\hline FO & G. miocenica & $183.7-193.2$ & $3.26-3.49$ \\
\hline \multicolumn{4}{|c|}{ Hole 664D } \\
\hline LO & G. obliquus extremus & $49.8-59.3$ & $1.20-1.40$ \\
\hline FO & G. truncatulinoides & $78.3-87.8$ & $1.80-1.95$ \\
\hline FO & G. inflata & $78.3-87.8$ & $1.80-1.95$ \\
\hline LO & G. exilis & $87.8-97.3$ & $1.95-2.2$ \\
\hline LO & G. miocenica & $97.3-106.8$ & $2.20-2.4$ \\
\hline Reapp. & Pulleniatina & $97.3-106.8$ & $2.20-2.4$ \\
\hline LO & G. puncticulata & $106.8-125.8$ & $2.40-2.8$ \\
\hline LO & G. altispira & $125.8-135.3$ & $2.80-3.0$ \\
\hline LO & S. seminulina & $125.8-135.3$ & $2.80-3.0$ \\
\hline LO & Pulleniatina spp. & $154.3-163.8$ & $3.38-3.57$ \\
\hline LO & G. margaritae & $173.3-182.8$ & $3.78-3.97$ \\
\hline FO & G. miocenica & $211.3-220.8$ & $4.60-4.80$ \\
\hline LO & G. nepenthes & $182.8-192.3$ & $3.97-4.18$ \\
\hline FO & G. crassaformis & $182.8-192.3$ & $3.97-4.18$ \\
\hline FO & G. puncticulata & $192.3-201.8$ & $4.18-4.38$ \\
\hline FO & G. margaritae & $230.3-239.8$ & $5.72-6.22$ \\
\hline LO & G. dehiscens & $230.3-239.8$ & $5.72-6.22$ \\
\hline FO & N. humerosa & $230.3-239.8$ & $5.72-6.22$ \\
\hline
\end{tabular}

Bermudez, 1965; Bolli and Premoli Silva, 1973; Stainforth et al., 1975; and Bolli and Saunders, 1985) to mark the middle/ late Miocene boundary.

Bolli and Premoli Silva used the FO of Neogloboquadrina humerosa, which has an age of $7.5 \mathrm{Ma}$ according to Berggren et al. (1985), to subdivide the late Miocene. Unfortunately, this datum lies in the missing cores in Hole $659 \mathrm{~A}$, and so its age cannot be refined beyond $8.20-10.50 \mathrm{Ma}$ at this site. In Hole 664D $N$. humerosa has its FO between 5.72-6.22 Ma, much younger than the expected 7.5 Ma. However, this is an interval of fairly strong dissolution, which may explain its absence. In Hole $667 \mathrm{~A}$ this species has its FO between 6.34-7.80 Ma.

\section{CONCLUSIONS}

The sites drilled on Leg 108 complete the north-south North Atlantic transect of HPC holes begun on Leg 94. Leg 108 has also provided sites in a variety of tropical environments including areas of upwelling, areas affected by cool surface currents, areas of strong dissolution, and warm water tropical sites. Site 667 can be regarded as the tropical end of the Leg 94 transect, and with few exceptions the datums at this site correspond with their published ages (ages which were largely determined in the tropics). Thus, diachronism of datums in the North Atlantic operates by species having progressively restricted ranges away from the tropics.

The sites affected by cool currents $(657,658,659,662,663$, and 664) show restricted species ranges similar to sites in the subtropics (e.g., Site 606). Particularly affected are such species as Globorotalia margaritae and Globorotalia nepenthes, which have been widely used as zonal markers. Other datums, such as the LOs of Globorotalia miocenica, Globorotalia puncticulata, Globoquadrina altispira, and Sphaeroidinellopsis seminulina, are reliable at all the sites studied.

\section{REFERENCES}

Banner, F. T., and Blow, W. H., 1965. Progress in the planktonic foraminifer biostratigraphy of the Neogene. Nature, 208:11641166.

Berggren, W. A., 1973. The Pliocene time scale: calibration of planktonic foraminifer and calcareous nannoplankton zones. Nature, 243:391-397.

1977a. Late Neogene foraminifer biostratigraphy of the Rio Grande Rise (South Atlantic). Mar. Micropaleontol., 2:265-313. 1977b. Late Neogene planktonic foraminifer biostratigraphy of DSDP Site 357 (Rio Grande Rise). In Perch-Nielsen, K., Supko, P. R., et al., Init. Repts. DSDP, 39: Washington (U.S. Govt. Printing Office), 591-614.

Berggren, W. A., Aubrey, M. P., and Hamilton, N., 1983. Neogene magnetobiostratigraphy of Deep-Sea Drilling Project Site 516 (Rio Grande Rise, South Atlantic). In Barker, P. F., Carlson, R. L., Johnson, D. A., et al., Init. Repts. DSDP, 72: Washington (U.S. Govt. Printing Office), 675-713.

Berggren, W. A., Kent, D. V., and Van Couvering, J. A., 1985. The Neogene: Part 2, Neogene geochronology and chronostratigraphy. In Snelling, N. J. (Ed.), The Chronology of the Geological Record. Geol. Soc. Mem. (London), 10:211-260.

Blow, W. H., 1969. Late middle Eocene to Recent planktonic foraminifer biostratigraphy. In Brönniman, P., and Renz, H. H. (Eds.), First International Conference on Planktonic Microfossils, Geneva, 1967: Leiden (E. J. Brill), 1:199-421.

Bolli, H. M., and Bermudez, P. J., 1965. Zonation based on planktonic foraminifera of middle Miocene to Pliocene warm-water sediments. Bol. Inf., Asoc. Venez. Geol. Min. Petrol., 8:119-149.

Bolli, H. M., and Premoli Silva, I., 1973. Oligocene to Recent planktonic foraminifera and stratigraphy of the Leg 15 sites in the Caribbean Sea. In Edgar, N. T., Saunders, J. B., et al., Init. Repts. DSDP, 15: Washington (U.S. Govt. Printing Office), 475497.

Bolli, H. M., and Saunders, J. B., 1985. Oligocene to Holocene low latitude planktic foraminifera. In Bolli, H. M., Saunders, J. B., and Perch-Nielsen, K. (Eds.), Plankton Stratigraphy: Cambridge (Cambridge Univ. Press), 155-262.

Cita, M. B., 1973. Pliocene biostratigraphy and chronostratigraphy. In Ryan, W.B.F., Hsü, K. J., et al., Init. Repts. DSDP, 13: Washington (U.S. Govt. Printing Office), 1343-1379.

Hodell, D. A., and Kennett, J. P., 1986. Late Miocene-early Pliocene stratigraphy and paleoceanography of the South Atlantic and Southwest Pacific oceans: a synthesis. Paleoceanography, 1:285311.

Iaccarino, S., and Salvatorini, G., 1982. A framework of planktonic foraminifer biostratigraphy for early Miocene to late Pliocene area. Paleontol. Stratigr. Evol., 2:115-125.

Kennett, J. P., 1973. Middle and late Cenozoic planktonic foraminifer biostratigraphy of the Southwest Pacific-DSDP Leg 21. In Burns, R. E., Andrews, J. E., et al., Init. Repts. DSDP, 21: Washington (U.S. Govt. Printing Office), 575-639.

Kennett, J. P., and Srinivasan, M. S., 1983. Neogene Planktonic Foraminifera: Stroudsberg, PA (Hutchinson Ross).

Krasheninnikov, V. A., and Pflaumann, U., 1978. Zonal stratigraphy of Neogene deposits of the eastern part of the Atlantic Ocean by means of planktonic foraminifers, Leg 41 Deep Sea Drilling Project. In Lancelot, Y., Seibold, E., et al., Init Repts. DSDP, 41: Washington (U.S. Govt. Printing Office), 613-657.

Rio, D., Sprovieri, R., and Raffi, I., 1984. Calcareous plankton biostratigraphy and biochronology of the Pliocene-lower Pleistocene succession of the Capo Rossello area, Sicily. Mar. Micropaleontol., 9:135-180.

Sarnthein, M., Thiede, J., Pflaumann, U., Erlenkeuser, H., Fütterer, D., Koopmann, B., Lange, H., and Seibold, E., 1982. Atmospheric and oceanic circulation patterns off northwest Africa during the past 25 million years. In von Rad, U., Hinz, K., Sarnthein, M., and Seibold, E. (Eds.), Geology of the Northwest 
Table 10. Distribution of planktonic foraminifers, Hole 662A.

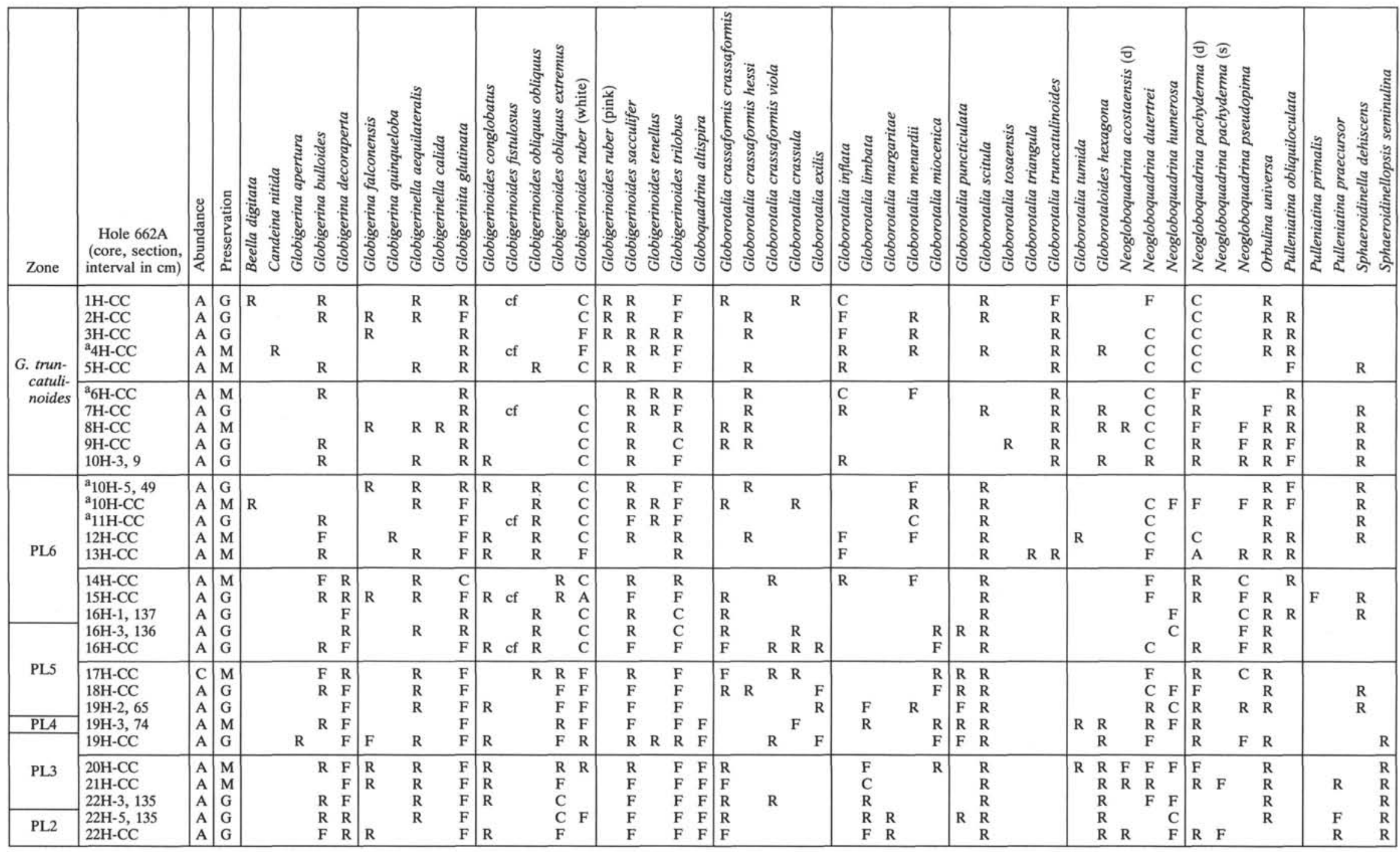

${ }^{a}$ Sample with a large number of reworked specimens. 
Table 11. Distribution of planktonic foraminifers, Hole 663A.

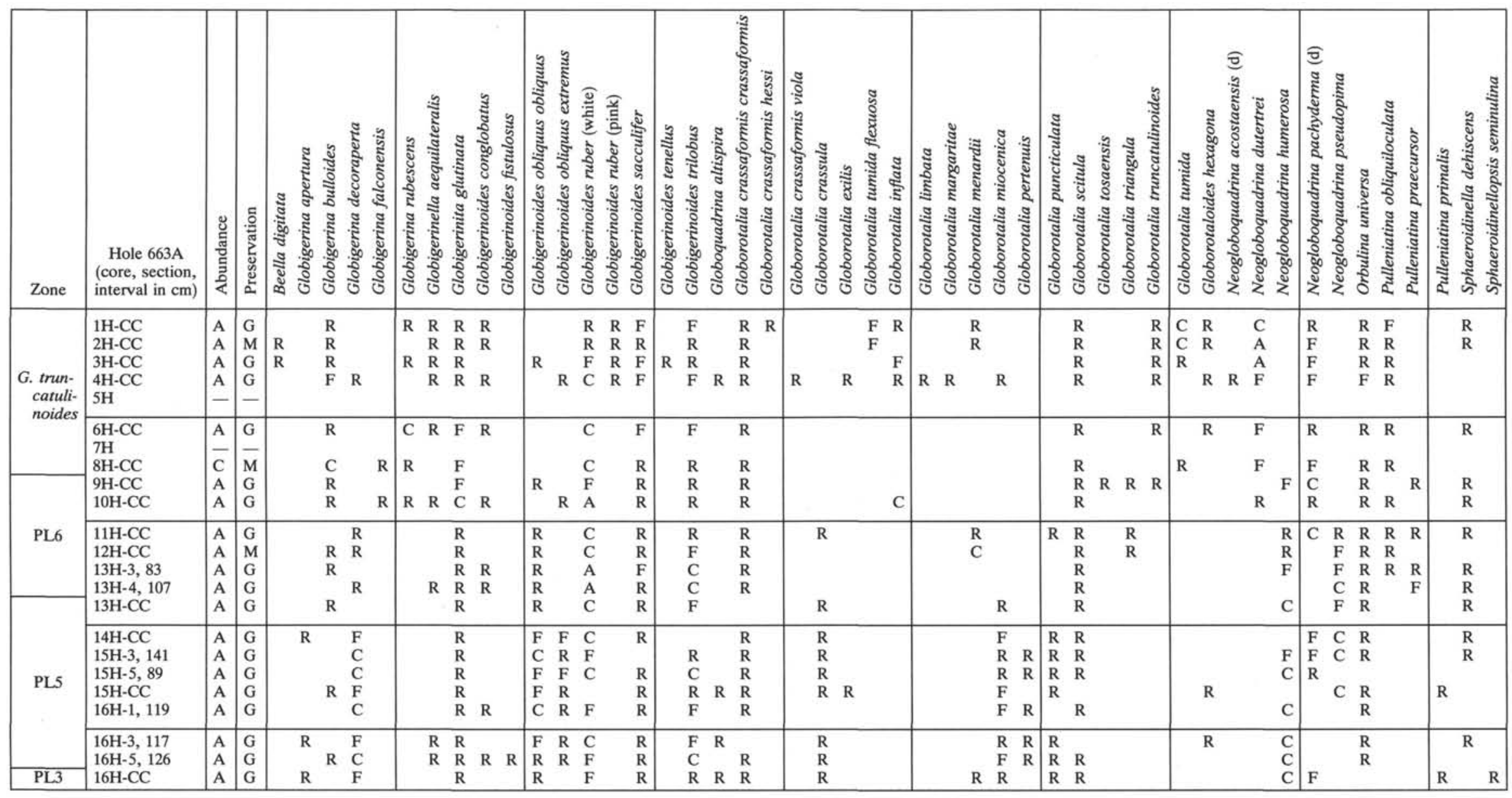


Table 12. Distribution of planktonic foraminifers, Hole 664D.

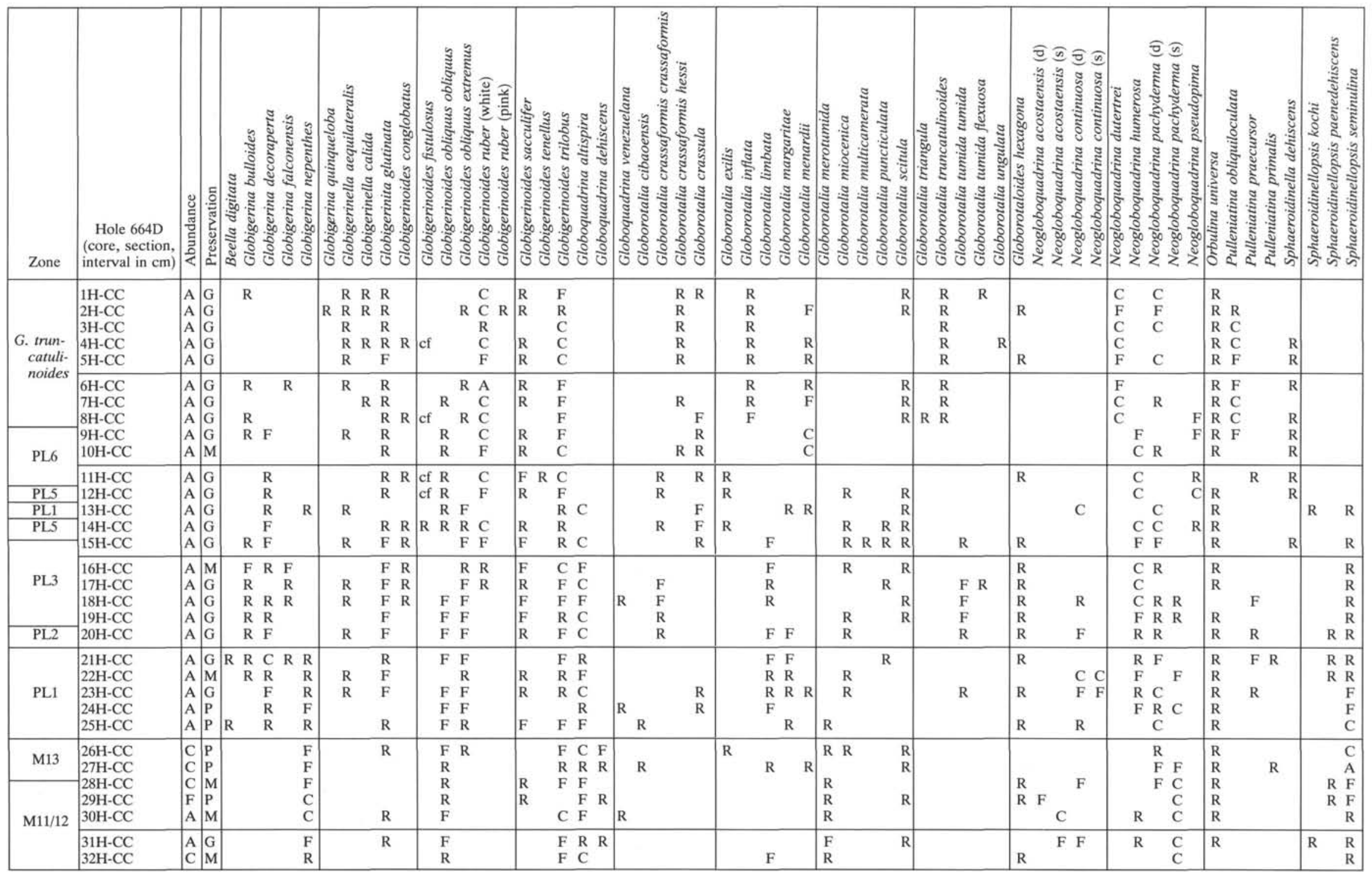


Table 13. Age and depth determinations of planktonic foraminifer datums in Sierra Leone Rise Holes 665A and 667A.

\begin{tabular}{|c|c|c|c|}
\hline Species & & $\begin{array}{l}\text { Depth } \\
\text { (mbsf) }\end{array}$ & $\begin{array}{l}\text { Age } \\
(\mathrm{Ma})\end{array}$ \\
\hline \multicolumn{4}{|l|}{ Hole $665 \mathrm{~A}$} \\
\hline LO & G. obliquus extremus & $46.1-50.4$ & $2.28-2.57$ \\
\hline FO & G. truncatulinoides & $21.9-31.4$ & $1.03-1.52$ \\
\hline FO & G. inflata & $40.9-46.1$ & $2.09-2.28$ \\
\hline LO & G. exilis & $40.9-46.1$ & $2.09-2.28$ \\
\hline LO & G. miocenica & $40.9-46.1$ & $2.09-2.28$ \\
\hline Reapp. & Pulleniatina & $40.9-46.1$ & $2.09-2.28$ \\
\hline LO & G. puncticulata & $40.9-46.1$ & $2.09-2.28$ \\
\hline LO & G. altispira & $52.6-55.7$ & $2.67-2.92$ \\
\hline LO & S. seminulina & $55.7-58.9$ & $2.92-3.13$ \\
\hline LO & Pulleniatina spp. & $69.4-69.9$ & $3.82-3.86$ \\
\hline \multicolumn{4}{|l|}{ Hole $667 \mathrm{~A}$} \\
\hline LO & G. obliquus extremus & $18.1-27.4$ & $1.10-2.00$ \\
\hline FO & G. truncatulinoides & $18.1-27.4$ & $1.48-2.00$ \\
\hline FO & G. inflata & $10.8-14.9$ & $0.76-1.05$ \\
\hline LO & G. exilis & $27.4-29.8$ & $2.00-2.18$ \\
\hline LO & G. miocenica & $27.4-29.8$ & $2.00-2.18$ \\
\hline Reapp. & Pulleniatina & $29.8-39.3$ & $2.18-2.68$ \\
\hline LO & G. puncticulata & $27.4-29.8$ & $2.00-2.18$ \\
\hline LO & G. altispira & $40.6-43.6$ & $2.72-2.05$ \\
\hline LO & S. seminulina & $40.6-43.6$ & $2.72-2.85$ \\
\hline LO & Pulleniatina spp. & $52.9-55.9$ & $3.32-3.50$ \\
\hline LO & G. margaritae & $52.9-55.9$ & $3.32-3.50$ \\
\hline $\mathrm{FO}$ & G. miocenica & $77.3-86.8$ & $4.56-5.70$ \\
\hline LO & G. nepenthes & $62.3-65.3$ & $3.80-3.98$ \\
\hline $\mathrm{FO}$ & G. crassaformis & $68.8-77.3$ & $4.12-4.56$ \\
\hline $\mathrm{FO}$ & G. puncticulata & $68.8-77.3$ & $4.12-4.56$ \\
\hline FO & G. margaritae & $96.3-105.8$ & $5.50-6.34$ \\
\hline LO & G. dehiscens & $77.3-86.8$ & $4.56-5.70$ \\
\hline LO & N. humerosa & $105.8-115.3$ & $6.34-7.80$ \\
\hline LO & N. acostaensis & $124.8-134.3$ & $8.60-10.30$ \\
\hline
\end{tabular}

African Continental Margin: Berlin-Heidelberg-New York (SpringerVerlag), 545-604.

Stainforth, R. N., Lamb, J. L., Luterbacher, H., Beard, J. H., and Jeffords, R. M., 1975. Cenozoic planktonic foraminifer zonation and characteristics of index forms. Univ. Kans. Paleontol. Contrib., Article 62.

Weaver, P.P.E., 1987. Late Miocene to Recent planktonic foraminifers from the North Atlantic: Deep Sea Drilling Project Leg 94. In Ruddiman, W. F., Kidd, R. B., Thomas, E., et al., Init. Repts. DSDP, 94, Pt. 2: Washington (U.S. Govt. Printing Office), 703727.

Weaver, P.P.E., and Clement, B. M., 1986. Synchroneity of Pliocene planktonic foraminifer datums in the North Atlantic. Mar. Micropaleontol., 10:295-307.

1987. Magnetobiostratigraphy of planktonic foraminifer datums: Deep Sea Drilling Project Leg 94, North Atlantic. In Ruddiman, W. F., Kidd, R. B., Thomas, E., et al., Init. Repts. DSDP, 94, Pt. 2: Washington (U.S. Govt. Printing Office), 815 829.

Zobel, B., 1973. Biostratigraphische untersuchungen an sedimenten des indisch-pakistanischen kontinentalrandes (Arabisches Meer). Meteor Forschungsergeb., Reihe C, 12:9-73.

Date of initial receipt: 17 February 1988

Date of acceptance: 5 December 1988

Ms 108B-130 


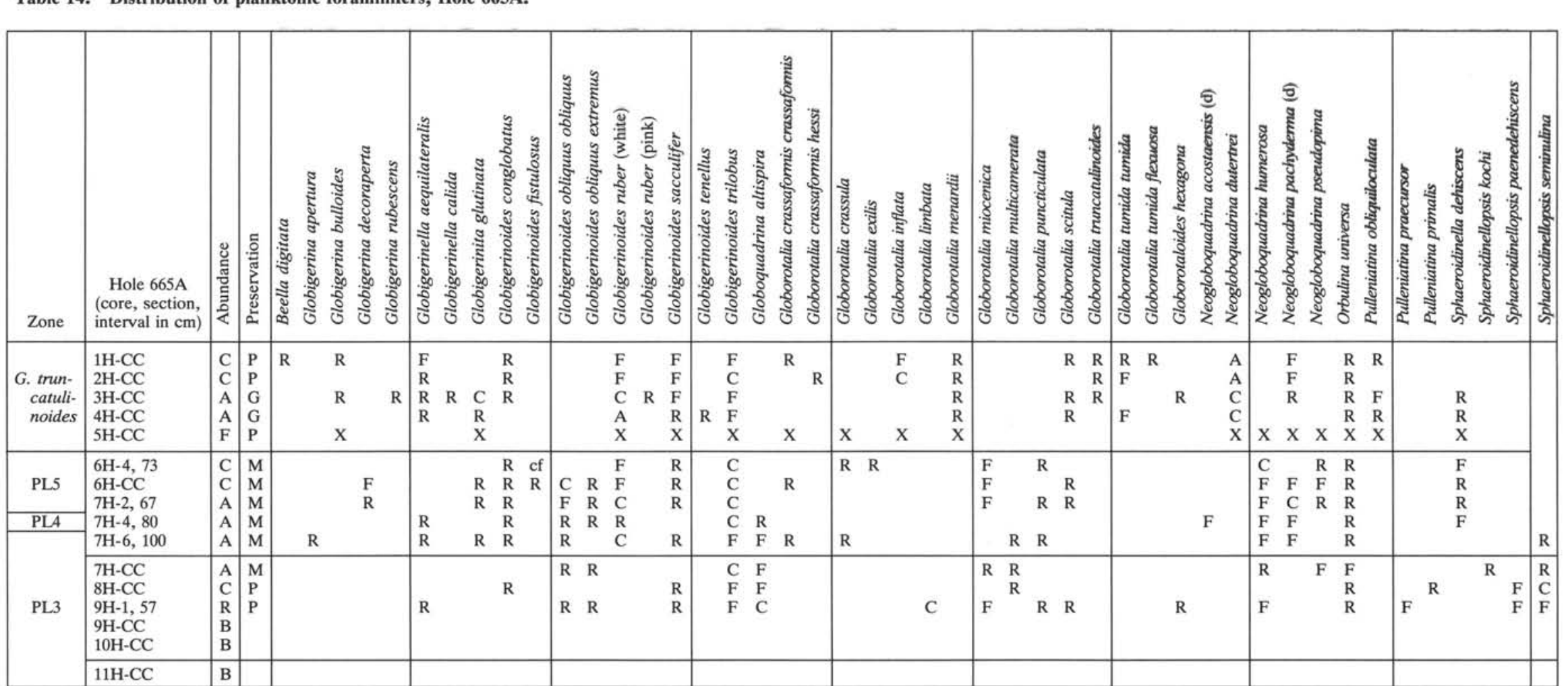


Table 15. Distribution of planktonic foraminifers, Hole 666A.

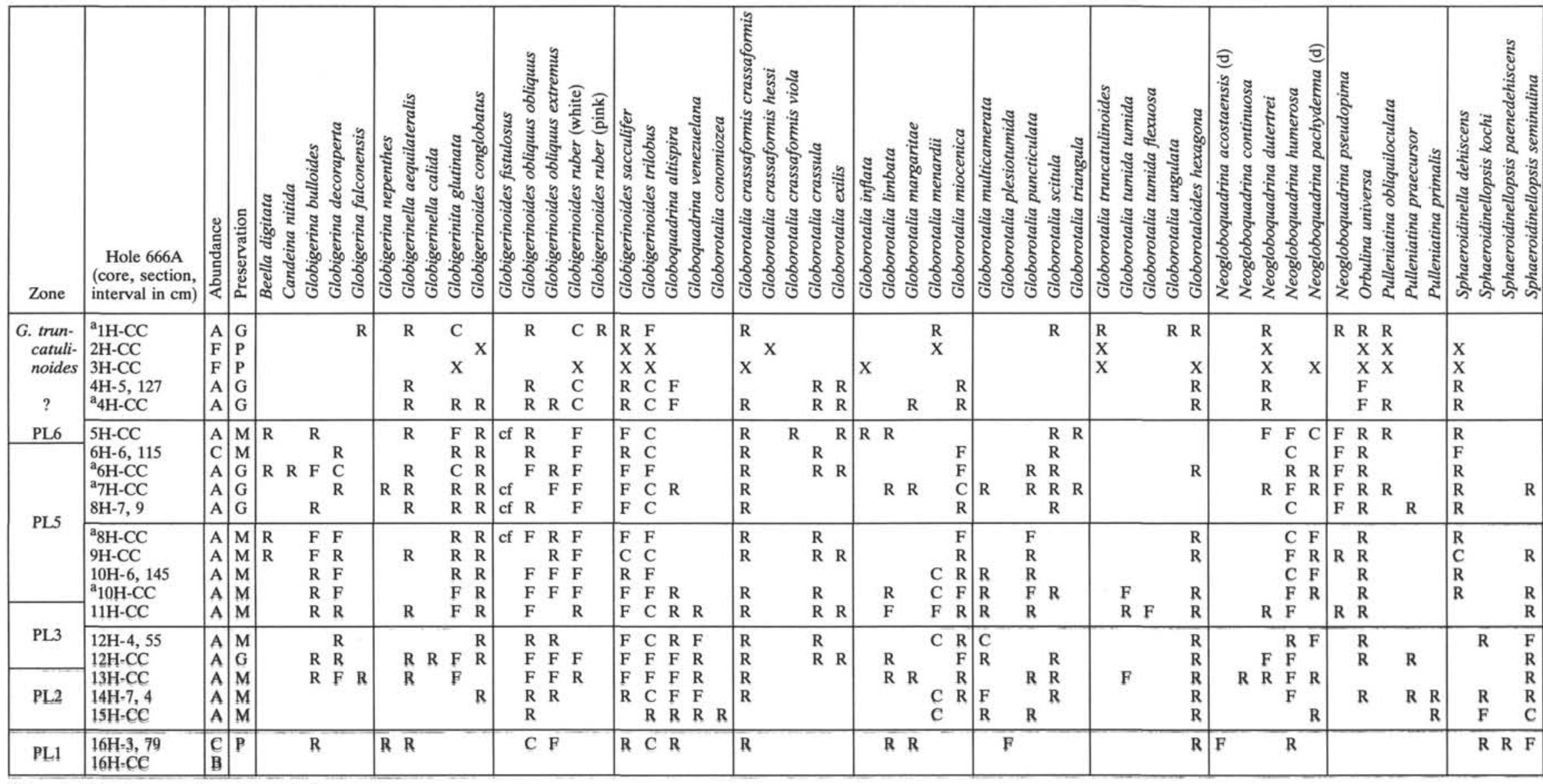

${ }^{\text {a }}$ Sample with a large number of reworked specimens. 
Table 16. Distribution of planktonic foraminifers, Hole 667A.

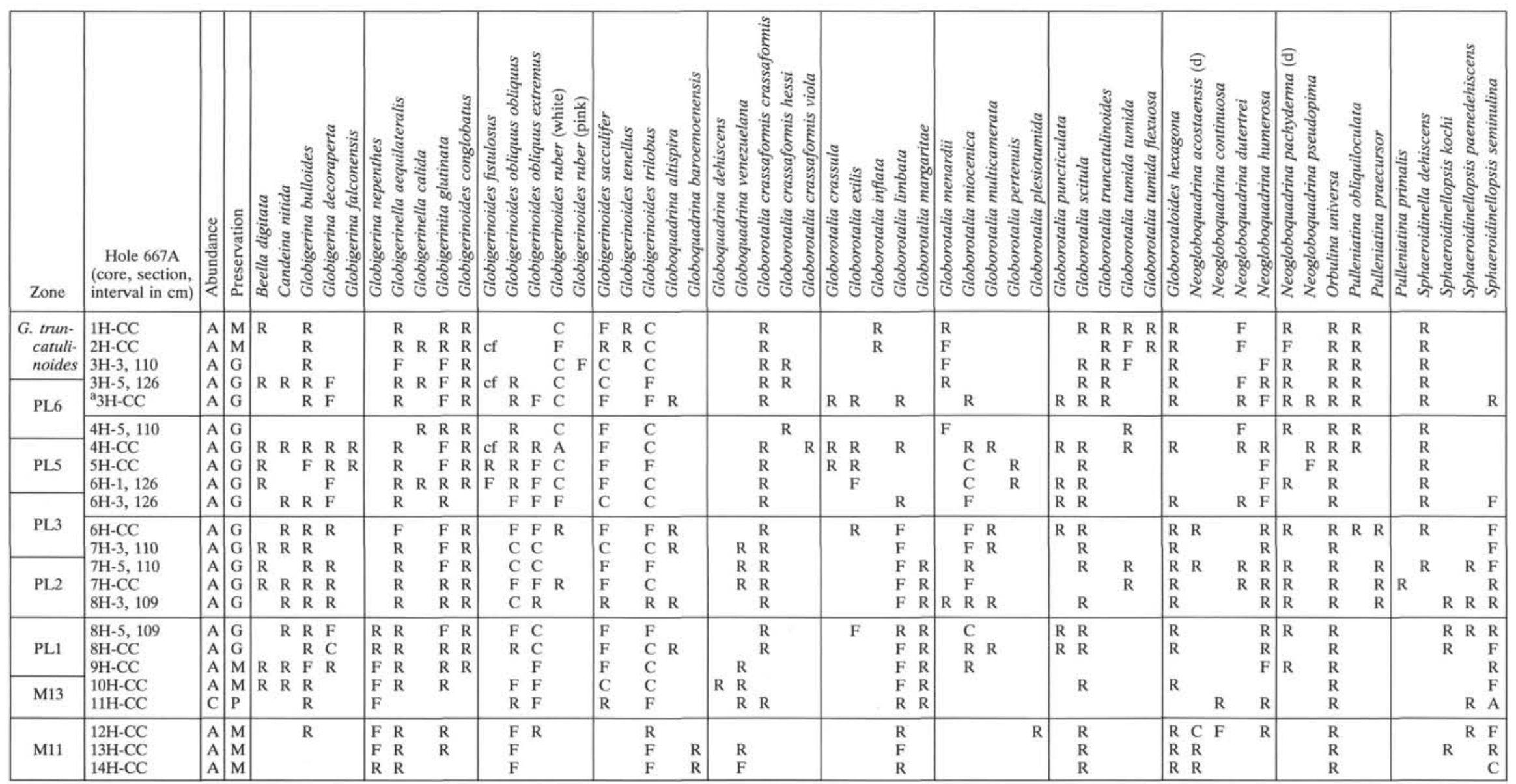

${ }^{\mathrm{a}}$ Sample with a large number of reworked specimens. 
Table 17. Distribution of planktonic foraminifers, Hole 668B.

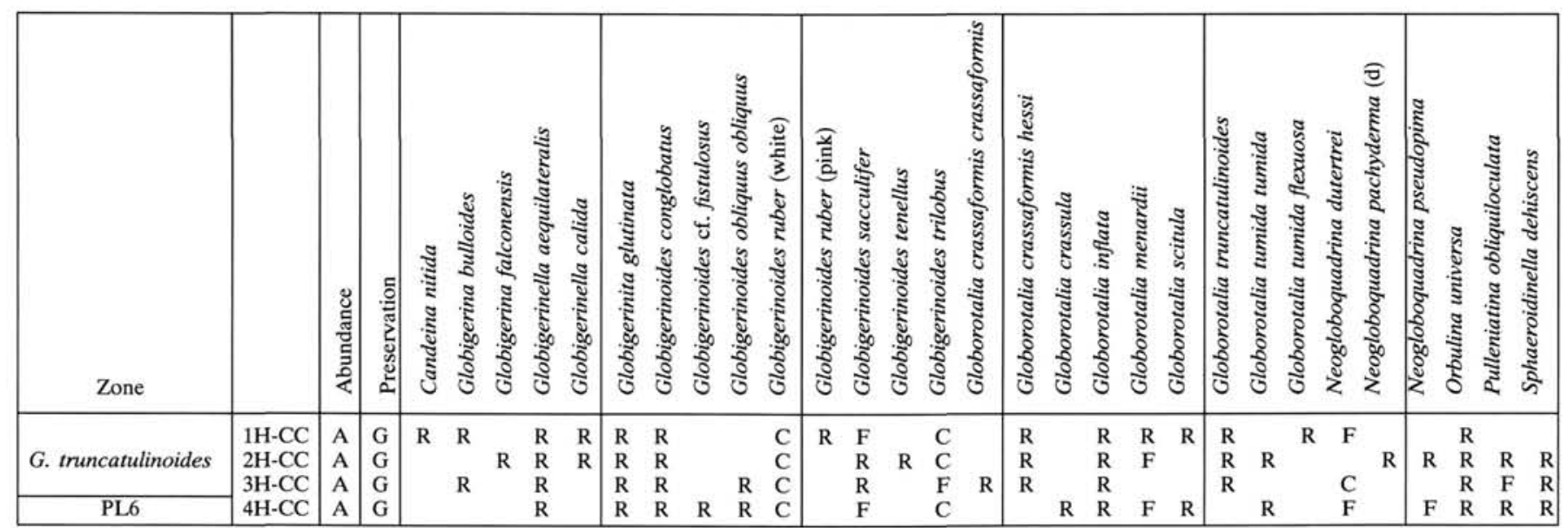

Table 18. Comparison of published ages of planktonic foraminifer datums (as given in Berggren et al., 1985) with measured ages in Leg 108 holes.

\begin{tabular}{|c|c|c|c|c|c|c|c|c|c|c|c|}
\hline \multirow[b]{3}{*}{ Species } & & \multirow{3}{*}{$\begin{array}{l}\text { Age } \\
\text { (Ma) }\end{array}$} & \multicolumn{9}{|c|}{ Sites and holes } \\
\hline & & & \multicolumn{3}{|c|}{ Canary Current } & \multicolumn{2}{|c|}{ Kane Gap } & \multicolumn{2}{|c|}{$\begin{array}{c}\text { Benguela } \\
\text { Current }\end{array}$} & \multicolumn{2}{|c|}{$\begin{array}{l}\text { Sierra Leone } \\
\text { Rise }\end{array}$} \\
\hline & & & 657 & 658 & 659 & 660 & 661 & 662 & 664 & 665 & 667 \\
\hline LO & G. obliquus extremus & 1.8 & c & -0.34 & c & ${ }^{a}-0.50$ & -0.50 & c & -0.40 & +0.48 & c \\
\hline FO & G. truncatulinoides & 1.9 & c & c & -0.30 & +0.05 & -0.90 & -0.38 & $\mathrm{c}$ & -0.38 & c \\
\hline FO & G. inflata & 2.1 & +0.05 & c & $\mathrm{c}$ & $\mathrm{c}$ & -0.14 & $\mathrm{c}$ & -0.15 & c & -1.05 \\
\hline LO & G. exilis & 2.1 & - & - & +0.10 & +0.15 & c & +0.14 & c & c & c \\
\hline LO & G. miocenica & 2.2 & c & +0.10 & $\mathrm{c}$ & +0.05 & c & $\mathrm{c}$ & c & c & c \\
\hline Reapp. & Pulleniatina & 2.2 & c & - & c & -0.03 & $\mathrm{c}$ & $\mathrm{c}$ & $\mathrm{c}$ & $\mathrm{c}$ & $\mathrm{c}$ \\
\hline LO & G. puncticulata & 2.3 & c & +0.06 & c & $\mathrm{c}$ & c & c & +0.10 & c & a -0.07 \\
\hline LO & G. altispira & 2.9 & +0.10 & c & c & c & c & $\mathrm{c}$ & c & $\mathrm{c}$ & $\mathrm{a}_{-0.05}$ \\
\hline LO & S. seminulina & 3.0 & c & c & c & +0.08 & c & c & c & c & $\mathrm{a}_{-0.15}$ \\
\hline LO & Pulleniatina spp. & 3.3 & +0.88 & - & c & c & c & c & +0.08 & +0.52 & $\mathrm{c}$ \\
\hline LO & G. margaritae & 3.4 & c & +0.20 & +0.05 & +0.44 & +0.34 & +0.19 & +0.38 & - & c \\
\hline FO & G. miocenica & 3.4 & c & - & +0.32 & -0.16 & c & $\mathrm{c}$ & +1.20 & - & +1.16 \\
\hline LO & G. nepenthes & 3.9 & +0.28 & - & +0.30 & c & c & - & +0.07 & - & c \\
\hline FO & G. crassaformis & 4.15 & +0.13 & - & +0.05 & c & -0.15 & - & $\mathrm{c}$ & - & c \\
\hline FO & G. puncticulata & 4.15 & +0.13 & - & +0.05 & -0.31 & -0.15 & - & +0.03 & - & c \\
\hline FO & G. mangaritae & 5.6 & -0.05 & - & +0.60 & - & -0.22 & - & +0.12 & - & c \\
\hline LO & G. dehiscens & 5.3 & - & - & +2.90 & - & $\mathrm{c}$ & - & +0.42 & - & c \\
\hline FO & N. humerosa & 7.5 & - & - & +0.70 & - & - & - & -1.28 & - & $\mathrm{c}$ \\
\hline FO & N. acostaensis & 10.2 & - & - & c & $=$ & - & - & - & - & - \\
\hline
\end{tabular}

Note: $-=$ younger than published age; $+=$ older than published age; and $\mathrm{c}=$ comparable with published age.

${ }^{\text {a }}$ Probably reworked. 